Invited research papers

\title{
Amphibians and reptiles as palaeonvironmental proxies during the Late Pleistocene (MIS3): The case of Stratigraphic Unit V of El Salt, Alcoi, Spain
}

\author{
Rafael Marquina-Blasco a,b, *, Ana Fagoaga ${ }^{\mathrm{a}, \mathrm{b}}$, Vicente D. Crespo ${ }^{\mathrm{c}, \mathrm{d}}$, Salvador Bailon ${ }^{\mathrm{e}, \mathrm{f}}$, \\ Carolina Mallol $^{\text {g,h }}{ }^{\text {, Cristo M. Hernández }}{ }^{i}$, Bertila Galván ${ }^{i}$, Francisco Javier Ruiz-Sánchez ${ }^{\text {a,b,j }}$ \\ ${ }^{a}$ GIUV2016-303 Cenozoic Vertebrates Research Group (PVC-GIUV), Palaeontology Area, Universitat de València, Dr. Moliner, 50, 46100 Valencia, Spain \\ ${ }^{\mathrm{b}}$ Museu Valencià d'Història Natural, L'Hort de Feliu, P.O. Box 8460, Alginet, Valencia, 46230, Spain \\ ${ }^{c}$ Consejo Nacional de Investigaciones Científicas y Técnicas, División de Paleontología de Vertebrados, Museo de La Plata (UNLP), Paseo del Bosque s/n, B1900FWA La \\ Plata, Argentina \\ ${ }^{\mathrm{d}}$ Museo Paleontológico de Alpuente, Av. San Blas 17, Alpuente, 46178 Valencia, Spain \\ ${ }^{\mathrm{e}}$ Histoire naturelle de l'Homme prehistorique, UMR 7194, CNRS, MNHN, Paris, France \\ ${ }^{\mathrm{f}}$ Archeozoologie, archeobotanique: societes, pratiques, environnements, UMR 7209, MNHN, CNRS, 55, rue Buffon, CP 55, 75005 Paris, France \\ ${ }^{\mathrm{g}}$ Instituto Universitario de Bio-Orgánica Antonio González (IUBO), Universidad de La Laguna, Santa Cruz de Tenerife, Spain \\ ${ }^{\text {h }}$ Departamento de Geografía e Historia, Universidad de La Laguna, Campus de Guajara, 38071, La Laguna, Santa Cruz de Tenerife, Spain \\ i Grupo de Investigación: "Sociedades cazadoras-recolectoras paleolíticas" UDI de Prehistoria, Arqueología e Historia Antigua, Facultad de Geografía e Historia, \\ Universidad de La Laguna, Campus de Guajara, 38071, La Laguna, Santa Cruz de Tenerife, Spain \\ ${ }^{\mathrm{j}}$ INCYT-UPSE, Universidad Estatal Península de Santa Elena, 7047 Santa Elena, Ecuador
}

\section{A R T I C L E I N F O}

\section{Keywords:}

Herpetofauna

MER

HWM

Palaeoclimate

Late Pleistocene

Iberian Peninsula

\begin{abstract}
A B S T R A C T
The locality of El Salt (Alcoi, Spain) is a key site for understanding the extirpation of Neanderthals in the eastern part of Iberia. In this paper, we analyse an assemblage of amphibians and reptiles from Stratigraphic Unit V $(45.2 \pm 3.4 \mathrm{ka}$ to $44.7 \pm 3.4 \mathrm{ka})$, which corresponds to one of the last regional records of Neanderthals, to improve knowledge of the palaeoecology and palaeoclimate of this event. The assemblage comprises three anurans (Pelodytes sp., Alytes obstetricans, and Epidalea calamita), two lizards (Lacertidae indet. and Chalcides bedriagai), and five snakes (Colubridae indet., Coronella sp., Coronella sp./Zamenis sp., Natrix maura, and Vipera latastei). Palaeoclimatic reconstruction, based on the Mutual Ecogeographic Range method, indicates that climate was cooler and slightly wetter climate than the present day climate of the Alcoi area. Applying the Habitat Weighting Method, we infer that the area surrounding El Salt was dominated by open dry regions, alternating with rocky areas with scarce scrubs and forest patches that would have developed under mesomediterranean conditions. These results are not entirely consistent with those obtained with other proxies (charcoal and small mammal assemblages) from the same site, which suggest slightly warmer and drier conditions. We hypothesise that these divergences may be partly related to the current wide distribution of reptiles and amphibians across Iberia. A key finding is that the extirpation of the Neanderthals in Iberia coincided with aridification.
\end{abstract}

\section{Introduction}

Palaeoecological and palaeoclimatic reconstructions are two of the primary topics in Quaternary studies, which are primarily concerned with the history of our species and own relatives (e. g. Cohen et al., 2009; deMenocal, 2011; Birks et al., 2015). Numerous proxies have been used to perform palaeoclimatic and palaeoecological reconstructions
(Bradley, 1999; Rose et al., 1999; d’Errico and Sánchez Goñi, 2003; Evershed et al., 2007; Birks et al., 2010; Wolf et al., 2018, among others). The use of a natural system as a climate proxy must meet two requirements: it must contain a climatic signal and have a modern relative for comparison and calibration purposes (the uniformitarianism principle) (Bradley, 1999). According to Bradley (1999), the biological proxies are related to the presence of a particular taxon, the fossil

\footnotetext{
* Corresponding author at: GIUV2016-303 Cenozoic Vertebrates Research Group (PVC-GIUV), Palaeontology Area, Universitat de València, Dr. Moliner, 50, 46100 Valencia, Spain

E-mail addresses: rafael.marquina@uv.es (R. Marquina-Blasco), ana.fagoaga@uv.es (A. Fagoaga), salvador.bailon@mnhn.fr (S. Bailon), cmallol@ull.es (C. Mallol), bgalvan@ull.es (B. Galván), francisco.ruiz@uv.es (F.J. Ruiz-Sánchez).
} 
assemblage, and its modern population distribution or its stable isotope composition.

Numerous marine cores allow for large-scale palaeoecological reconstructions in Quaternary sites, although it is not entirely clear that they can be applied to continental contexts (Jennerjahn et al., 2004; Beghin et al., 2016). Unfortunately, few continental cores can be used for this purpose (e.g. d'Errico and Sánchez Goñi, 2003; Sepulchre et al., 2007). Moreover, according to Holmes et al. (2010), only a specific-site reconstruction in which human remains have been found could provide a valuable environmental context for studying hominin evolution.

Although amphibians and reptiles have traditionally received less attention than mammals in palaeontological sites, they can be highly useful for clarifying some palaeoclimatic and landscape aspects of the study area. As ectothermic animals, they are quite sensitive to environmental and habitat changes; they also have low dispersal capabilities (Antúnez et al., 1988; Bailon and Rage, 1999; Araújo and Pearson, 2005; Rodríguez et al., 2005). Due to these characteristics, these specimens provide important local information on the climatic and ecological conditions that prevailed during the formation of the archaeological and palaeontological sites, as well as the possible effects of these conditions on Late Pleistocene human communities. For these reasons, in the last 10 years, amphibian and reptiles assemblages have been widely used as palaeoclimatic and palaeoenvironmental proxies (Blain, 2009; Cruz et al., 2016; Blain et al., 2018, 2019; Villa et al., 2018a, 2018b). Therefore, numerous studies have examined on the palaeoclimatic and palaeoecological implications of both herpetofaunal and/or small mammal assemblages (e.g. López-García et al., 2011a, 2011b, 2012a, 2012b, 2012c, 2014; Blain et al., 2013; Rey-Rodríguez et al., 2016; Marquina et al., 2017) in order to elucidate the local context of the Neanderthals demise.

Neanderthals were a human species that inhabited Europe and the Middle East during the late-Middle and Late Pleistocene (e. g. Finlayson, 2004). The disappearance of Neanderthals ocurred during Marine Isotope Stage (MIS) 3 (ca., 30-60 ka in accordance with Railsback et al. (2015)) (e.g. Mallol et al., 2012). This was an unstable climatic period in the Late Pleistocene that was characterised by alternating warm phases with expanding forests and cold phases when semi-arid areas developed (e.g. Fletcher and Sánchez-Goñi, 2008). A classical hypothesis proposed to explain the extinction of Neanderthals postulates competition and subsequent replacement by anatomically modern humans (AMH) (Mellars, 2004). However, direct contact between Neanderthals and AMH has not been directly confirmed in the Iberian Peninsula, apparently the last region inhabited by Neanderthals (e.g. Vaquero et al., 2006; Mallol et al., 2012). Human remains are scarce in the Late Pleistocene sites of the Iberian Peninsula (Strauss, 2018); therefore, their presence or absence is based on indirect evidence, such as lithic tools. It seems well established that Neanderthals manufactured Mousterian tools (Vaquero et al., 2006) whereas it is generally assumed that Aurignacian technology was produced by AMH (Vaquero et al., 2006). However, this attribution is highly controversial (Strauss, 2018). Moreover, there are several problems regarding the proposed dates for contact between both human populations: the studied period is close to the practical limit for radiocarbon dating; postdepositional disturbance processes on dated elements and archaeological evicences cannot be discarded; diagnostic elements in the lithic assemblage are lacking; and finally, some proposed radiocarbon dates are inaccurate due to the use of inadequate pretreatment protocols (Wood et al., 2013). These factors contribute to the uncertainty regarding the timing and possible causes of the Neanderthal extinction.

Some hypotheses for the Neanderthal disappearance focus on climate change and its environmental effects (e.g. Bradtmöller et al., 2012; Mallol et al., 2012), even though, during their existence, Neanderthals successfully coped with an unstable climate (Van Andel, 2003). These humans were severely affected by cold periods (Finlayson et al., 2001; Bradtmöller et al., 2012), and their distribution reached its northernmost limit during warm intervals (Stewart, 2005). Thus, extirpation events and the abandonment of sites were common throughout Neanderthal history (Trinkaus, 1995). In this sense, the traditional view of this species as cold-adapted (Pearson, 2000) is doubtful (Finlayson, 2005). Recent studies of Neanderthal anatomy indicate certain traits that are actually characteristic of temperate-zone mammals (Aiello and Wheeler, 2004; Rae et al., 2011) and suggest that the robustness anatomical features of these humans are actually related to a powerful mode of locomotion (sprinting) (Stewart, 2005; Stewart et al., 2019). Moreover, the associated fauna in Neanderthal sites seem to be adapted to warm climatic conditions (Stewart, 2004; Finlayson and Carrión, 2007); for example, in Wallou Cave (Belgium), where occupation apparently alternated between Neanderthals and collared lemmings, an open cold-adapted species ocurred (Stewart et al., 2019). Thus, the available palaeocological evidence, along with Neanderthals' general anatomy, palaeogenomics, and likely ambush hunting behaviour (Schmitt et al., 2003) all seem to indicate that Neanderthals preferred warm forested habitats instead of cold open steppes (Stewart et al., 2019).

At the beginning of MIS 3, Neanderthals were nearly ubiquitous, although their distributional range was gradually shrinking towards the south (e.g. Stewart, 2009). Finally, they were limited to the Iberian Peninsula before their extinction (e.g. Finlayson and Giles-Pacheco, 2000). At the end of its existence, they apparently consisted of small and isolated populations living in a reduced ecological niche (Melchionna et al., 2018). The final demise of Neanderthals probably took place during Heinrich Event (HE) 4 (ca. 40.2-38.3 ka) (Bradtmöller et al., 2012) or just before its onset (ca. $40.2 \mathrm{ka}$ ) (Wood et al., 2013; Galván et al., 2014a; Wolf et al., 2018). In the Mediterranean coastal areas, this HE provoked severe aridity episodes (Sepulchre et al., 2007). However, according to Wolf et al. (2018), during MIS 3, the climate deterioration does not seem to have coincided with HE 4, at least in the interior area of the Iberian Peninsula.

The Middle Palaeolithic site of El Salt (Alcoi, Spain) is a key locality for studying the extirpation of Neanderthals in southeastern Spain. Its high value lies in the fact that the archaeological sequence of El Salt records different occupation phases, in which a transition from recurrent to sporadic human occupation -and finally, an abandonment of the sitehave been identified (Galván et al., 2014a). Moreover, El Salt contains a rich lithic and vertebrate faunal assemblage, along with combustion structures and six Neanderthal teeth, possibly belonging to an individual from one of the last groups in the region (Garralda et al., 2014). The vertebrate faunal assemblage succession allows for studying and interpretating both the climatic evolution in the southeastern Iberian Peninsula during the Middle Palaeolithic and the possible impact of these changing climatic features on the local palaeoecology and, therefore, on the human populations inhabiting this zone. The aim of this study is to reconstruct the environmental conditions prevailing in Stratigraphic Unit (SU) V from the El Salt site, based on the amphibian and reptile assemblages. Our results are discussed within the debate about the Neanderthal extinction, focusing on the ecological context in which these events occurred.

\section{Geological setting}

The archaeological site of El Salt (Alcoi, Alicante) $(716,673$, $4,284,952$, 30S) (Fig. 1) rests against a $38 \mathrm{~m}$-high Paleocene limestone wall at $680 \mathrm{~m}$ above sea level (a.s.l.). The wall is the result of a trust fault of Eocene limestone over Paleocene conglomerates. The presence of the limestone stopped the course of the Barxell River in the upper part of the wall, creating a palaeolake that outflowed over the fault. As a result, a large travertinic building was created along more than $2.5 \mathrm{~km}$ in the foothills of the Serra de Mariola (Galván et al., 2014b).

According to Fumanal García (1994), the sedimentary sequence consists of thirteen lithostratigraphic units, which can be grouped into five segments based on their macroscopic textural appearance and archaeological content (Galván et al., 2014b) (Fig. 2a). From base to top, 


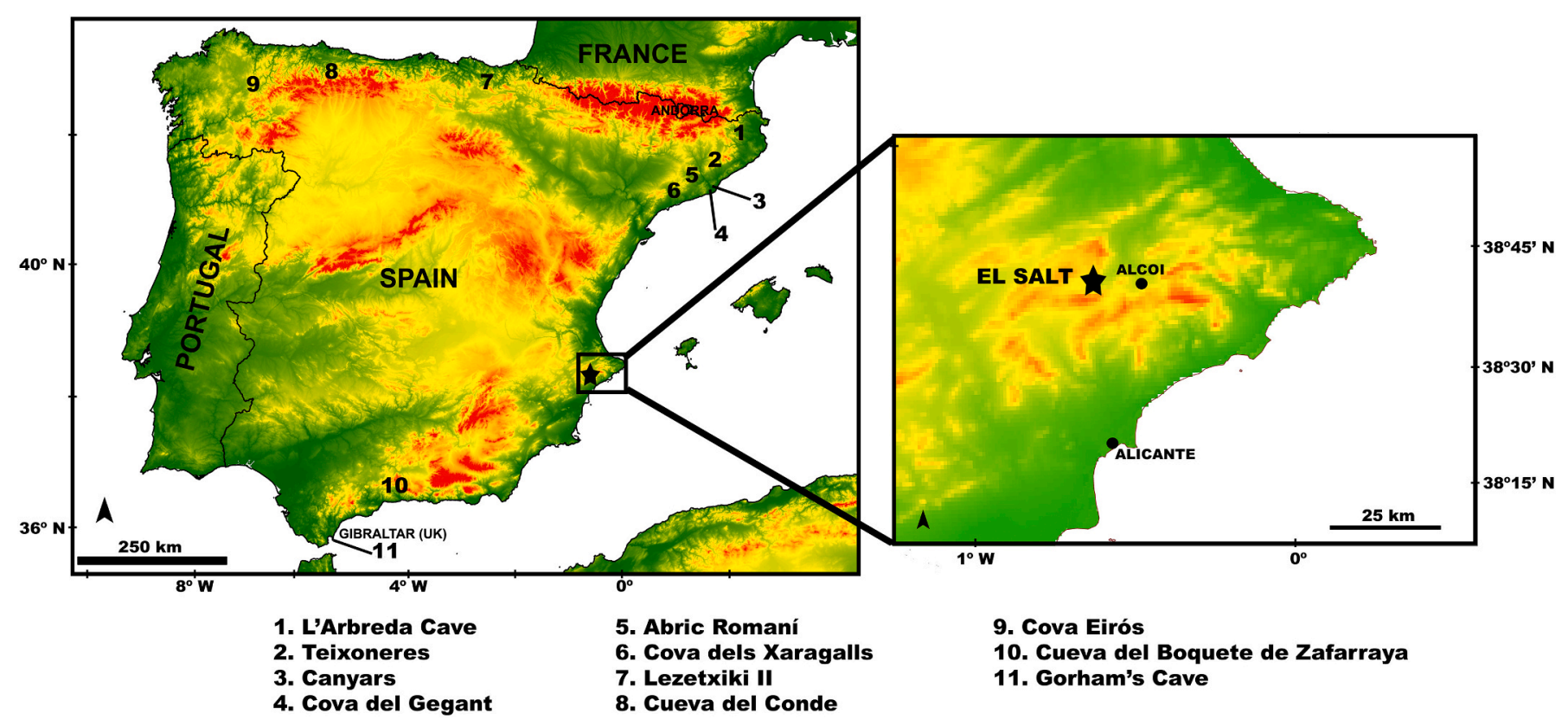

Fig. 1. Geographic location of the El Salt site (black star) in the Iberian Peninsula together with other MIS 3 localities mentioned in the text.

SU XIII is a subhorizontal travertine platform of unknown thickness. The top of this unit has been dated by U/Th as $81.5 \pm 2.7 \mathrm{ka}$ and $80.1 \pm 4 \mathrm{ka}$ (MIS 5a- ca. 82-71 ka) (Galván et al., 2014b). Whereas SU XIII is archaeologically sterile, the stratigraphic units SU XII to SU IX contain the highest concentration of archaeological remains and combustion features within the entire sequence. As a whole, these units consist of $1.5 \mathrm{~m}$ of horizontally bedded fine sand, with several large blocks at their base related to a first episode of roof collapse (Galván et al., 2014b). This part of the sequence has been dated, using thermoluminescence (TL), as $60.7 \pm 8.9 \mathrm{ka}$ (SU XII) and $52.3 \pm 4.6$ ka (SU X) (Galván et al., 2014a), placing the sequence at the beginning of MIS 3, before event HE 5 (Galván et al., 2014a). In contrast, from SU VIII to the middle part of SU $\mathrm{V}$, human occupation evidences decrease and become spatially reduced. SU VI is covered by a significant accumulation of large blocks, produced by the collapse of the roof of the travertine structure. Six teeth attributed to a juvenile or young adult Neanderthal were recovered from the base of SU V (Garralda et al., 2014). These remains may represent one of the last occurrences of Neanderthals in the region (Garralda et al., 2014). The top of SU VI has been dated by TL as between $52.3 \pm 4.6$ and $47.2 \pm$ $4.4 \mathrm{ka}$, whereas the base of SU V has been dated by optically stimulated luminescence (OSL) as $45.2 \pm 3.4$ ka (Galván et al., 2014a). The middle part of SU V has been dated by OSL as $44.7 \pm 3.2 \mathrm{ka}$, before HE 4 (40.2-38.3 ka) (Galván et al., 2014a). The upper part of SU V consists of a $50 \mathrm{~cm}$-thick layer, truncated by a Holocene erosive episode. It is constituted by massive sandy silt with heterogeneous gravel in the top $20 \mathrm{~cm}$, from which two small flint blades, a few undifferentiated flakes, and a small combustion structure have been recovered (Garralda et al., 2014). Finally, SU IV to I consist of a $1.3 \mathrm{~m}$-thick constituted by irregular beds of gravel and cobbles in a silty, clayey matrix. These SU are in a secondary position and separated by erosional contacts. In this deposit, Neolithic pottery mixed with lithic remains from the late Upper Palaeolithic, Epipalaeolithic, and Mesolithic have been recorded (Galván et al., 2014a).

\section{Material, methods and abbreviations}

The material we describe in this paper consists primarly of disarticulated elements collected during the 2013 and 2014 archaeological campaigns at El Salt. The excavation methodology implemented at the El Salt site is based on the identification of stratification planes through sharp stratigraphic contacts, textural or lithological changes, and the presence of large objects, which identify the various palaeosurfaces. The remains studied here come from Upper Unit V: specifically, layers V-24, including excavation surfaces (S) 9,8 , and 7, from youngest to oldest, and V-25 (Fig. 2b). Both layers have been dated around $45 \mathrm{ka}$ - that is, between HE 5 and HE 4 (Galván et al., 2014a). A total weight of 101.46 kg (V-25: 14.66 kg; V-24 S7: 23.42 kg; V-24 S8: 26.00 kg; V-24 S9: 37.38 $\mathrm{kg}$ ) of sediment was sieved for this study.

Fossils were obtained from two distinct sources: i) sieving of the sediment using superimposed nested sieves of successively sized screens $(5,2,1.25,1,0.75$, and $0.5 \mathrm{~mm})$, and ii) flotation with a $1-\mathrm{mm}$ mesh during the process of separating macrobotanical remains from the sediment (see Vidal-Matutano, 2016). Unlike method (i) (sieving), with the flotation technique (ii) only the coarser fractions $(>1 \mathrm{~mm}$ ) were recovered; therefore, fossils obtained through flotation were only recorded as presence/absence data. Fossils were picked, sorted, and classified under a Leica MS5 binocular microscope. Measurements were taken with a Leica MZ75 binocular microscope connected to Sony Magnescale measuring equipment. Photographs were taken with a HITACHI 4800 scanning electron at the Servei Central de Suport a la Investigació Experimental (SCSIE) of the Universitat de València.

Herpetological fossils were assigned to different taxa following the criteria given by Bailon (1991, 1999), Sanchiz (1998), and Blain (2009) for Amphibia remains and following Szyndlar (1984), Barbadillo (1989), Bailon (1991), Barahona (1996), Barahona and Barbadillo (1997), Szyndlar and Rage (1999), and Blain (2009) for Squamata. Comparisons were carried out using the collections of dry skeletons of the Museo Nacional de Ciencias Naturales (CSIC) (Madrid, Spain), Muséum national d'Histoire naturelle (MNHN) (Paris, France), Gabinet de Fauna Quaternària of the Museu de Prehistòria de València (Valencia, Spain), and the Departament de Botànica i Geologia from the Universitat de València (Burjassot, Spain). The osteological nomenclature follows Roček (1984), Szyndlar (1984), and Bailon (1991, 1999). We follow the taxonomic nomenclature of Speybroeck et al. (2020) for reptiles and amphibians. All measurements were taken following Barahona (1996) and Barahona and Barbadillo (1997) for lacertids, and following Auffenberg (1967) and Blain (2009) for snakes.

The study of the palaeoclimatic and palaeoecological changes along the sequence are based on the study of the assemblage of amphibians and reptiles from SU Xb-11 S3 (Marquina et al., 2017). The 


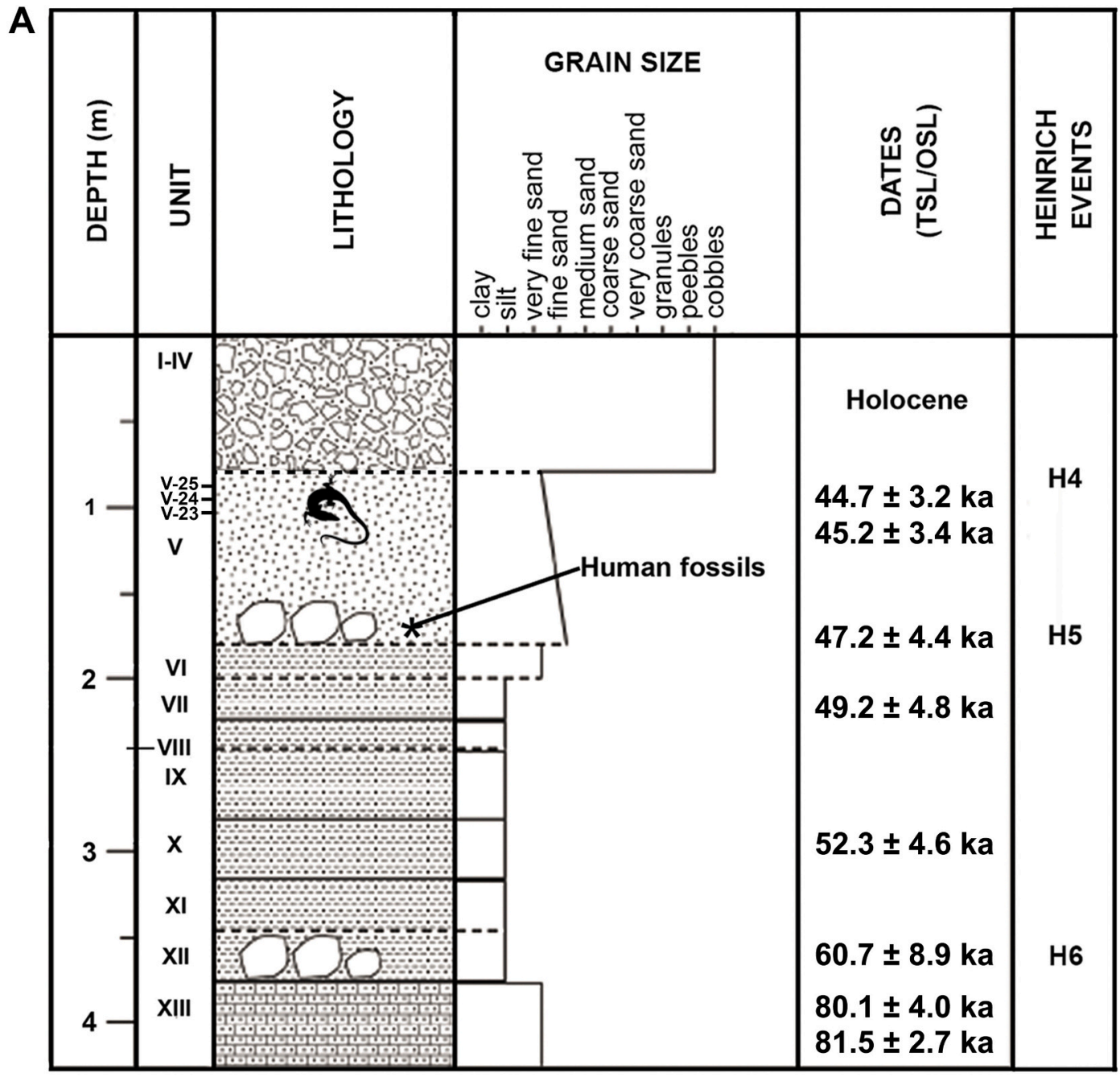

B

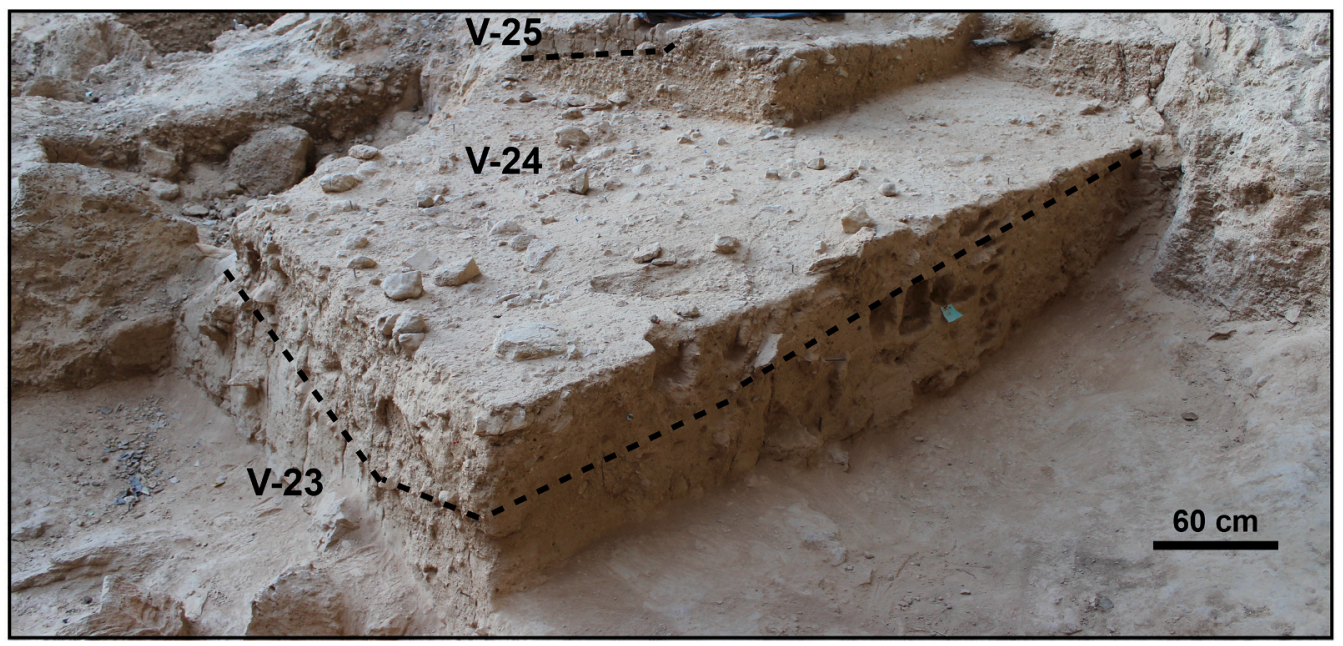

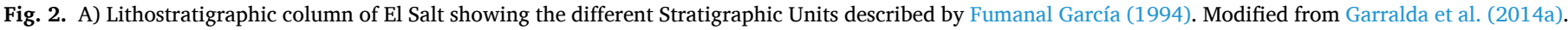

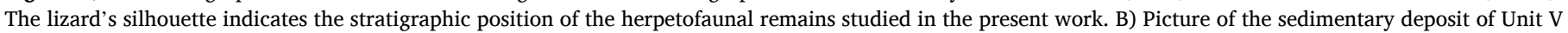
where the amphibian and reptile remains were recovered (Upper Unit V-24 and V-25). Modified from Fagoaga et al. (2019).

consideration of all these units (SU Xb and SU V) allows us to compare different moments of human occurrence.

To reconstruct the environment of SU V, we have applied the Habitat Weighting Method (HWM) (Evans et al., 1981; Andrews, 2006), which depends on the relative abundances of the different species determined in the assemblage. Therefore, only the material collected with the water- sieving method (which considers all of the size fractions) was used here. HWM is based on distributing each amphibian and squamate taxon in the habitat(s) where they can be found currently in the Iberian Peninsula. With the exception of a few residual Early Pleistocene taxa (Bailon and Blain, 2007; Blain et al., 2016a; Blain and Bailon, 2019), Iberian Pleistocene amphibians and squamate reptiles are specifically identical 
to modern populations (Bailon, 1991; Barbadillo et al., 1997; Blain, 2009). Based on these assumptions, the current species habitat distribution may be used for calculating the habitat-weighting index of taxa described in this work. In the original method, the habitats were sorted into five types (Cuenca-Bescós et al., 2005; Blain et al., 2008): (I) opendry, (II) open-humid, (III) woodland, (IV) rocky areas, and (V) water edges (areas surrounding water bodies). Each species was given a proportional score depending on its occurrence in one or more habitats. The maximum possible score for each taxon is 1.00 . Subsequently, all of these scores are related to the minimum number of individuals (MNI) to obtain the percentage weight of each species in the various assemblages. The distribution data are taken from multiple studies in the Iberian Peninsula (Pleguezuelos et al., 2002; Loureiro et al., 2008) and from palaeonvironmental reconstructions based on HWM (Blain et al., 2011a, 2011b; López-García et al., 2011a, 2012a, 2012b, 2012c, 2013, 2014; Burjachs et al., 2012; Rey-Rodríguez et al., 2016; Garcia-Ibaibarriaga et al., 2018).

To conduct the palaeoclimatic reconstruction, we apply the Mutual Ecogeographic Range (MER) method (Blain, 2009; Blain et al., 2016b). This technique is based on the modern biogeographic co-ocurrence of species described in a palaeontological or archaeological site. We have considered here the entire Iberian Peninsula, an area with natural geographical limits. The choice of this analytical unit is also supported by the fact that some species, that could potentially appear in the site are Iberian endemisms (e.g. Chalcides bedriagai). The biogeographic cartography of amphibians and reptiles for Spain is provided by the Servidor de Información de Anfibios y Reptiles de España (SIARE) (AHE, 2016); for Portugal, it is provided by Loureiro et al. (2008). Using ArcGis $9.1 \circledR$, the climatic parameters are estimated by overlapping the coocurrence areas and the current climate layers with a 30-arcseconds resolution grid from WorldClim 1.4 (Hijmans et al., 2005). Both sets of data (co-ocurrence areas and climate layers) are represented in the same spatial reference system (EPSG 25830, ETRS 1989 UTM datum coordinate projection system). The bioclimatic parameters extracted from the cartography supplied by Hijmans et al. (2005) are: BIO 1 (mean annual temperature), BIO 5 (maximum temperature of the warmest month), BIO 6 (minimum temperature of the coldest month), BIO 7 (temperature annual range), BIO 12 (annual precipitation), BIO 13 (precipitation of the wettest month), and BIO 14 (precipitation of the driest month).

To reconstruct the vegetal landscape and its bioclimatic determinants existing around the site at the time of its formation, we related (with the aid of GIS tools) the cartography of vegetation series in the Iberian Peninsula (Rivas-Martínez, 1987) to the mutual distribution range of the fossil species (currently extant) recorded in $\mathrm{SU} \mathrm{Xb}$ and $\mathrm{V}$ at El Salt. We compared these results to those of the present vegetal landscape and the bioclimatic indices that characterise the surroundings of the site (Alcoi municipality), according to Rivas-Martínez (1987).

Finally, we conducted a preliminary taphonomic study of the reptiles and amphibians of SU V to discern the agent(s) responsible for the fossil accumulation and to verify the degree of reliability of the information provided by the fossil assemblages. Our taphonomical approach is based primarily on Pinto Llona and Andrews (1999), Stoetzel et al., 2011, Lebreton et al. (2020), and Bisbal-Chinesta et al. (2020a). These authors have studied skeletal representation, as well as bone fragmentation and modification. Thus, to identify the degree of preservation of skeletal elements per carcass, we calculated the ratio of the number of identifiable skeletal parts (NISP) to the minimum number of individuals (MNI) for every taxon described here.

The material described in this study is temporally housed in the Departament de Botànica i Geologia of the Universitat de València (Burjassot, Spain) until their definitive storage in the Museu Arqueològic Municipal Camil Visedo Moltó (Alcoi, Spain).

The abbreviations used in this text are as follows: AHE (Asociación Herpetológica Española); AMH (anatomically modern humans); $\mathrm{H}$ (months with probability of frost); HWM (Habitat Weighting Method);
HE (Heinrich Event); M (average of the maximum temperatures of the coldest month); It (thermicity index); $m$ (average of the minimum temperatures of the coldest month); MAT (mean annual temperature); MAP (mean annual precipitation); MER (Mutual Ecogeographic Range method); MIS (marine isotope stage); MNI (minimum number of individuals); MinTC (minimum temperature of the coldest month); MaxTW (maximum temperature of the warmest month); NISP (number of identifiable skeletal parts); OD (Open Dry habitat); OH (Open Humid habitat); R (Rocky habitat); SCSIE (Servei Central de Suport a la Investigació Experimental, Universitat de València); $S$ (excavation surface); SU (Stratigraphic Unit); TL (thermoluminescence dating method); W (Water habitat); WO (Woodland habitat).

\section{Results}

\subsection{Herpetofaunal assemblage}

A total of 551 remains of reptiles and amphibians were recovered from El Salt V-24 and V-25; they belong to 95 individuals distributed among 12 species. The association include three anurans (Pelodytes sp., Alytes obstetricans and Epidalea calamita), two lizards (Lacertidae indet. and Chalcides bedriagai) and five snakes (Colubridae indet., Coronella sp., Coronella sp. or Zamenis sp., Natrix maura, and Vipera latastei) (Table 1; Fig. 3). The description of the recovered material can be found in Supplementary Material 1. In general, all taxa are distributed throughout the entire sequence, except for some species that are only present in a particular surface, such as Natrix maura in V24-S8, along with Pelodytes sp. and Coronella sp. or Zamenis sp. in V24-S9.

The herpetofaunal assemblage described here is composed of species widely distributed in the Iberian Peninsula (Pleguezuelos et al., 2002; Loureiro et al., 2008). With the exception of Alytes obstetricans, Epidalea calamita, and Natrix maura, which can be found outside the Iberian Peninsula, the rest of the species are Iberian endemisms (i.e. Vipera latastei and Chalcides bedriagai). Multiple authors (i.e. Vargas and Real, 1997; Sillero et al., 2009) have found the existence of two major chorotypes among the Iberian herpetofauna (Atlantic and Mediterranean), which are extremely coincident with the geoclimate and biogeography of the region. The species recovered from SU V are included within the Mediterranean chorotype of the Iberian herpetofauna, characterised by a wide distribution throughout the Mediterranean bioregion of the Iberian Peninsula and a broad presence in various habitat types (Sillero

Table 1

Comparative faunal list from Stratigraphic Units Xb (Marquina et al., 2017) and V (this work) at El Salt.

\begin{tabular}{|c|c|c|c|c|c|}
\hline & \multirow{3}{*}{$\frac{\frac{X b}{11}}{\mathrm{~s} 3}$} & \multicolumn{4}{|l|}{$\mathrm{V}$} \\
\hline & & \multicolumn{3}{|l|}{24} & \multirow{2}{*}{$\frac{25}{-}$} \\
\hline & & S9 & S8 & S7 & \\
\hline Anura indet. & 0 & 0 & 0 & 0 & 0 \\
\hline Pelodytes sp. & 0 & 1 & 0 & 0 & 0 \\
\hline Alytes obstetricans & 1 & 1 & 1 & 1 & 1 \\
\hline Epidalea calamita & 1 & 1 & 1 & 1 & 1 \\
\hline Bufo bufo s.l. & 1 & 0 & 0 & 0 & 0 \\
\hline Blanus cinereus s.l. & 1 & 0 & 0 & 0 & 0 \\
\hline Lacertilia indet. & 0 & 1 & 1 & 1 & 1 \\
\hline Chalcides bedriagai & 1 & 1 & 1 & 1 & 1 \\
\hline Lacertidae indet. & 0 & 1 & 1 & 1 & 1 \\
\hline cf. Acanthodactylus erythrurus & 1 & 0 & 0 & 0 & 0 \\
\hline Serpentes indet. & 0 & 1 & 1 & 1 & 1 \\
\hline Colubridae indet. & 0 & 1 & 1 & 1 & 0 \\
\hline Coronella sp. & 0 & 1 & 0 & 1 & 0 \\
\hline Coronella sp./Zamenis sp. & 0 & 1 & 0 & 0 & 0 \\
\hline cf. Zamenis scalaris & 1 & 0 & 0 & 0 & 0 \\
\hline Natrix maura & 0 & 0 & 1 & 0 & 0 \\
\hline Vipera latastei & 0 & 1 & 0 & 1 & 0 \\
\hline
\end{tabular}

The faunal list of surfaces V-24 S9, V-24 S8, V-24 S7 and layer V-25 reflects only the material recovered with the sieving method. 1: presence; 0 : absence. 


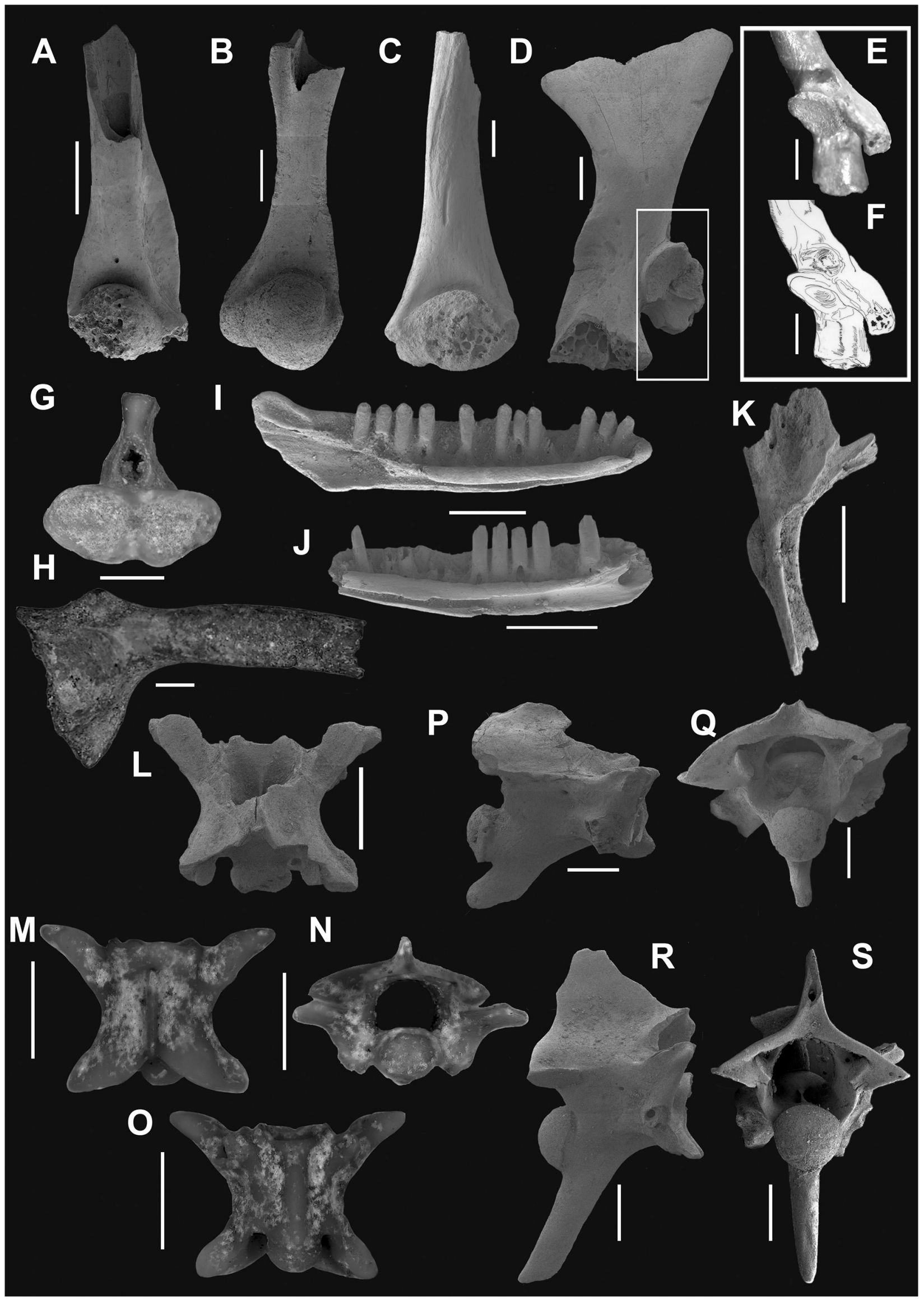




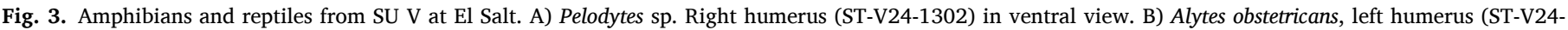

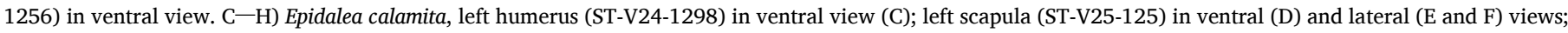

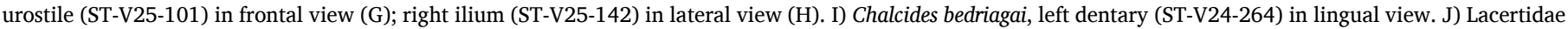

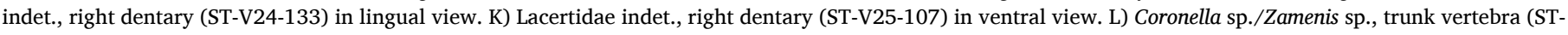

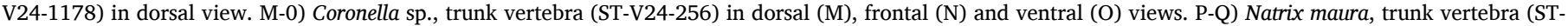

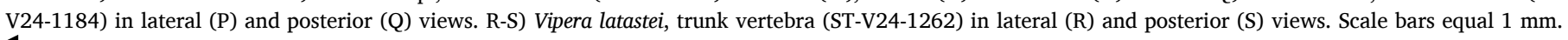

et al., 2009).

\subsection{Taphonomical approach}

Although taphonomical studies of micromammals are common, those addressing herpetofauna are scarce (Lyman, 1994; Bailon, 2011). In fact, papers exclusively focused on amphibian and/or reptilian taphonomy are extremely rare (Pinto Llona and Andrews, 1999; Stoetzel et al., 2011; Bisbal-Chinesta et al., 2020a); they have usually been incidental to other studies (i. e., Castillo et al., 2001). However, some observations can be made. At El Salt, the herpetological remains show very few marks of digestion, whereas weathering or chemical alteration marks are common (Fig. 4a). There is a high degree fragmentation; intact bones are extremely rare. The fracture plane is primarily angular due to the fragmentation in situ after its deposition. No fossils show abraded or polished surfaces or edges, which suggests short or null transport prior to their burial. The colour of the remains is homogeneous, without remarkable differences. Root marks and black traces (Fig. 4b) are rare on the surface of the studied material. The lack of intense digestion marks (Fig. 4c) on some remains suggests that they could have been accumulated by owls, whose gastric juice action on bones is smoother than that in carnivorous mammals (Pinto Llona and Andrews, 1999). The preliminary taphonomic study of the small mammals from SU V at El Salt suggests the European eagle owl (Bubo bubo) as the most plausible agent for the concentration of this assemblage (Fagoaga et al., 2019). Bubo bubo is characterised by a wide range of prey (Lebreton et al., 2020); however, amphibians and reptiles generally constitute only sporadic prey for the European eagle owl, at least in Mediterranean ecosystems (Jasić and Marti, 1984). Nevertheless, some individual owls have been reported to show some degree of

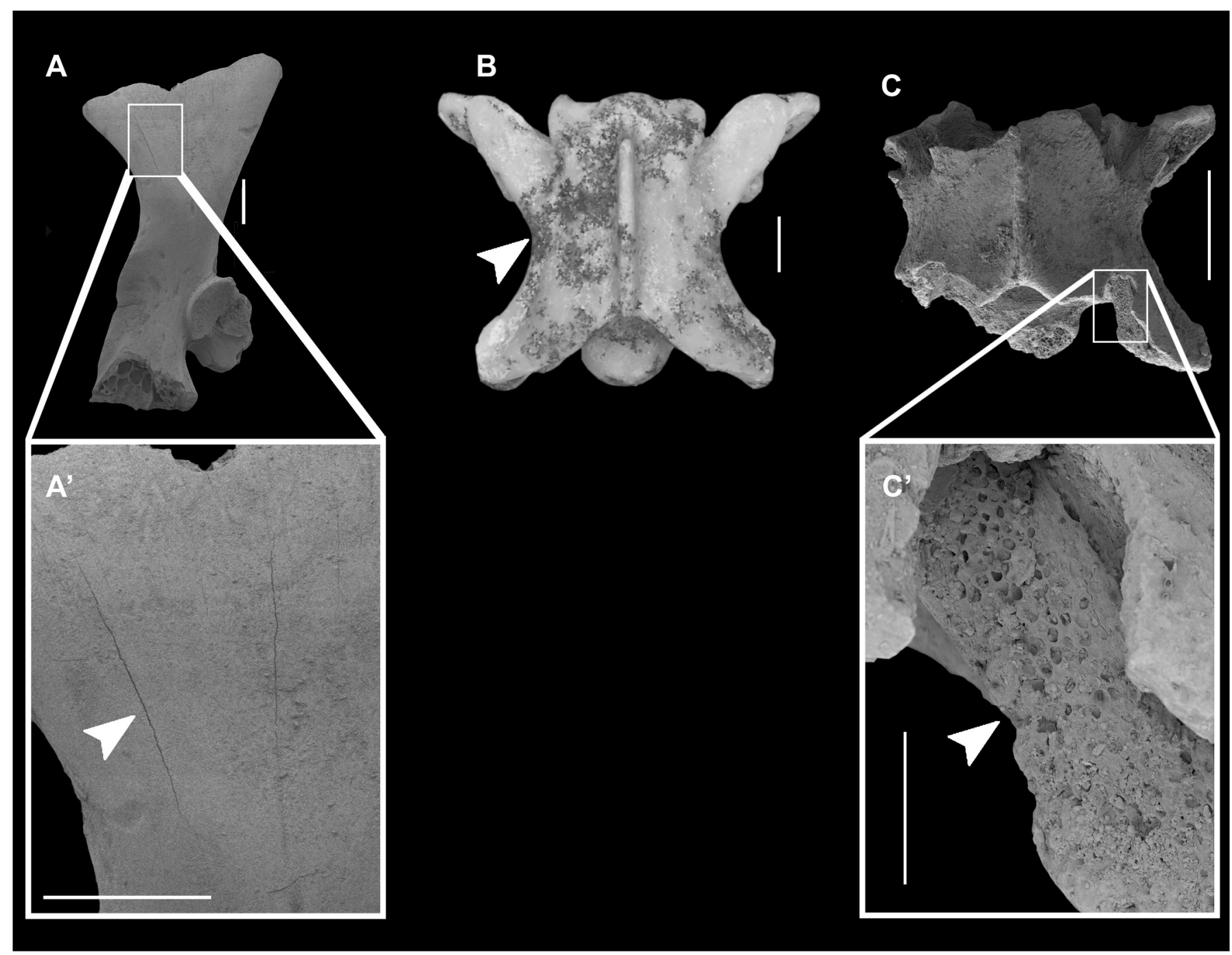

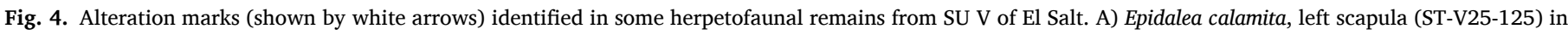

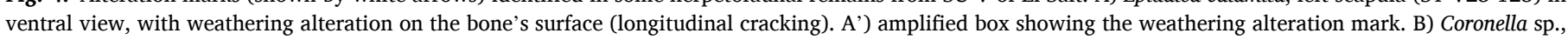

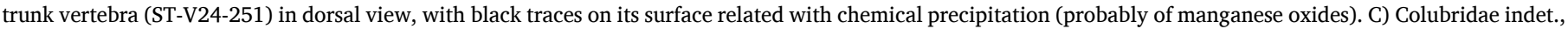
trunk vertebra (ST-V24-1202) in dorsal view, with digestion marks. $\mathrm{C}^{\prime}$ ) amplified box showing the digestion alteration mark. 
specialisation on amphibians (Andrews, 1990). Bisbal-Chinesta et al. (2020a) describe a fossil assemblage clearly dominated by Hyla gr. arborea (representing $84 \%$ of the association). The taphonomic analysis suggests that the assemblage was generated by the predation of a medium-large nocturnal raptor (possibly B. bubo or Strix aluco). This is an interesting case of opportunistic exploitation of an abundant seasonal resource during the reproductive agglomerations of that anurans (Bisbal-Chinesta et al., 2020a). However, predation is not the only process responsible for herpetological taphocoenosis (Cochard, 2004). Reptiles and amphibians use caves and rock fissures for brumation and/or aestivation as a response to changes in weather conditions (Vitt and Caldwell, 2013). The lack of digestion marks also may be attributed to natural death as the primary origin for at least part of the assemblage. Unfortunately, the absence of studies focusing on the taphonomy of reptiles and amphibians precludes further conclusions about the possible biological agents that produced this accumulation.

Table 2 shows the values of NISP and MNI from the material recovered with the sieving method. Supplementary Material 2 includes the results yielded by both the sieving method and the flotation method.

\subsection{Palaeoenvironmental reconstruction}

The application of the HWM method to the different assemblages recorded in SU V (V-24 S7, S8, and S9, as well as V-25) of the El Salt site indicates a landscape dominated by an Open Dry habitat (OD) throughout the sample studied (Table 3; Fig. 5a). The reconstruction shows a peak of clearly dominant Open Dry habitats, at V-25, which could be related to a scenario of higher aridity. Moreover, Fig. 5 shows an increasing trend of Open Dry habitat values from the oldest samples to the youngest. Pelodytes sp., Epidalea calamita, and Chalcides bedriagai suggest the presence of dry meadows under seasonal climate change. Conversely, the Open Humid habitat $(\mathrm{OH})$ - represented by the presence of Alytes obstetricans, Coronella sp., and Vipera latastei - undergoes, generally the opposite evolution, with a decreasing tendency from older to younger surfaces (V-24 S9: 6\%; V-24 S8: 7\%; V-24 S7: 7\%; V-25: 4\%) (Fig. 5).

The rocky areas habitat $(R)$ shows high values throughout the studied SUs, with its highest value (28\%) in V-24 S7 and the lowest value in V-24 S8 (23\%) (Table 3). Taxa linked to rocky habitats are Coronella sp., Epidalea calamita, and Vipera latastei (Table 2). Additionally, rocky areas provide abundant fissures, that can be used by trogophilic species such as Pelodytes sp. (Thomas and Triolet, 1994).

The Woodland habitat type (WO) shows an erratic evolution. The highest values are obtained in V-24 S7 (27\%) and V-24 S9 (26\%); the lowest values are obtained in V-25 (23\%) and V-4 S8 (22\%) (Table 3).

In general, the presence of the water-related habitat $(W)$ is anecdotal,
Table 3

Results of the palaeoclimatic reconstruction after the application of the Habitat Weighting Method to the fossil assemblage of amphibians and reptiles.

\begin{tabular}{llllll}
\hline & OD & OH & WO & R & W \\
\hline Xb-11 S3 & 27 & 24 & 30 & 6 & 13 \\
V-24 S9 & 38 & 6 & 26 & 27 & 3 \\
V-24 S8 & 35 & 7 & 22 & 23 & 13 \\
V-24 S7 & 38 & 7 & 27 & 28 & 1 \\
V-25 & 45 & 4 & 23 & 27 & 1 \\
\hline
\end{tabular}

Data for layer Xb-11 S3 are from Marquina et al. (2017).

except in the case of V-24 S8. This anomalous value is due to the presence of Natrix maura in the recovered fossil association. The only limiting factor in the distribution of this species is the presence of water bodies in the environment (Santos et al., 2002; Santos, 2008); for this reason, its entire ecosystem weight is recorded in the water habitat type. Only a single individual of Natrix maura $(\mathrm{MNI}=1)$ has been found in V$24 \mathrm{~S} 8$, although it represents $7 \%$ of all the individuals (14) recovered from this sample (14). Thus, the 'percentage weight'in the results of this taxon is elevated. In fact, if we remove $N$. maura, the Open Dry is the most important habitat in the sample (39\%) followed by Rocky (26\%) and Woodland (25\%) habitats. The occurrence of Alytes obstetricans and Natrix maura indicates permanent water bodies in the surrounding area of El Salt, while Pelodytes sp. and Epidalea calamita are indicators of ephemeral water bodies. The palaeoenvironmental reconstruction given here should be taken with caution, considering the low MNI (13-23 individuals) yielded by the different studied surfaces of SU V.

\subsection{Palaeoclimatic reconstruction}

The results of the application of the MER method are represented in Fig. 6. The absence of grids in the south of the Iberian Peninsula derived from the mutual distribution area linked to $\mathrm{SU} \mathrm{V}$ is explained by the distribution of Alytes obstetricans (Fig. 5). On the other hand, the lack of records in the northernmost regions of the peninsula results from the absence in these regions of species such as Chalcides bedriagai and Vipera latastei (Pleguezuelos et al., 2002; Loureiro et al., 2008) (Fig. 6). Finally, the discontinuous distribution of $V$. latastei, present primarily in mountainous regions (Saint Girons, 1980), results in the discrimination of a large number of grid units, especially in those regions outside of mountainous systems (Fig. 5). The mutual distribution area is located primarily in the eastern and western Iberian Peninsula. The absence of records in the central region is probably related to areas containing low herpetological data, such as the Southern Plateau (Pleguezuelos et al., 2002; Sillero et al., 2009).

The samples we study here suggest a palaeoclimatic scenario similar

Table 2

Minimum number of individuals, percentage and habitat classification of the species from Unit V at El Salt.

\begin{tabular}{|c|c|c|c|c|c|c|c|c|c|c|c|c|c|c|c|c|c|}
\hline & \multicolumn{3}{|c|}{ V-24 S9 } & \multicolumn{3}{|c|}{ V-24 S8 } & \multicolumn{3}{|c|}{ V-24 S7 } & \multicolumn{3}{|l|}{ V-25 } & \multicolumn{5}{|c|}{ Habitat Weighting Method } \\
\hline & NISP & MNI & $\%$ & NISP & MNI & $\%$ & NISP & MNI & $\%$ & NISP & MNI & $\%$ & OD & $\mathrm{OH}$ & WO & $\mathrm{R}$ & $\mathrm{W}$ \\
\hline Pelodytes sp. & 1 & 1 & 4 & & & & & & & & & & 0.5 & & 0.2 & 0.1 & 0.2 \\
\hline Alytes obstetricans & 2 & 1 & 4 & 2 & 1 & 8 & 4 & 1 & 5 & 6 & 1 & 6 & & 0.6 & 0.2 & & 0.2 \\
\hline Epidalea calamita & 8 & 1 & 4 & 9 & 1 & 8 & 4 & 1 & 5 & 26 & 3 & 18 & 0.75 & & & 0.25 & \\
\hline Chalcides bedriagai & 31 & 11 & 48 & 26 & 6 & 46 & 35 & 11 & 58 & 31 & 10 & 59 & 0.4 & & 0.3 & 0.3 & \\
\hline Lacertidae indet. & 29 & 4 & 17 & 12 & 2 & 15 & 18 & 3 & 16 & 14 & 3 & 18 & & & & & \\
\hline Colubridae indet. & 4 & 2 & 8 & 4 & 2 & 16 & 1 & 1 & 5 & & & & & & & & \\
\hline Coronella sp. & 3 & 1 & 4 & & & & 6 & 1 & 5 & & & & 0.125 & 0.375 & 0.25 & 0.25 & \\
\hline Coronella sp./Zamenis sp. & 2 & 1 & 4 & & & & & & & & & & & & & & \\
\hline Natrix maura & & & & 1 & 1 & 8 & & & & & & & & & & & 1 \\
\hline Vipera latastei & 2 & 1 & 4 & & & & 1 & 1 & 5 & & & & 0.375 & & 0.25 & 0.375 & \\
\hline TOTAL & 149 & 23 & 100 & 111 & 13 & 100 & 103 & 19 & 100 & 123 & 17 & 100 & & & & & \\
\hline
\end{tabular}

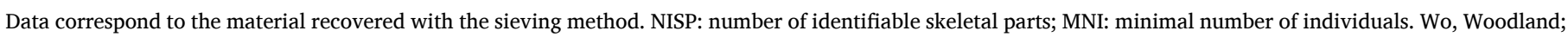

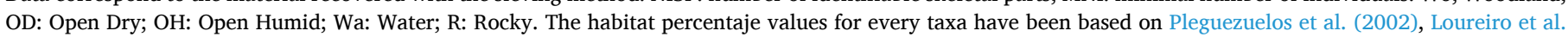

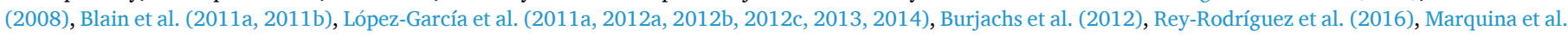
(2017) and Garcia-Ibaibarriaga et al. (2018). 


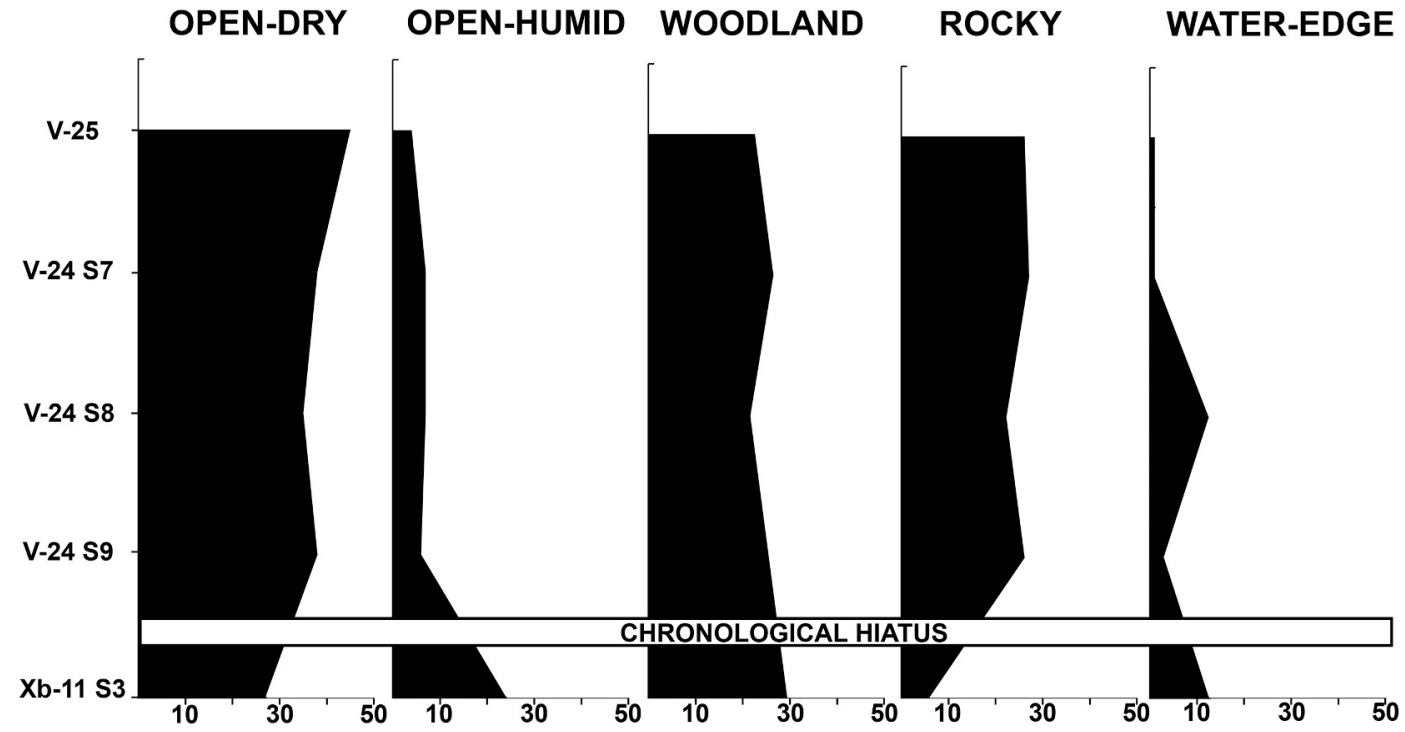

Fig. 5. Palaeoenvironmental reconstruction of El Salt based on fossil herpetofauna from the different surfaces of SU V (S9, S8 and S7 in V-24, and V25) and SU Xb (S3) (Marquina et al., 2017). The reconstruction is based on the herpetofaunal association.

A) $\mathrm{Xb}-11 \mathrm{S3}$

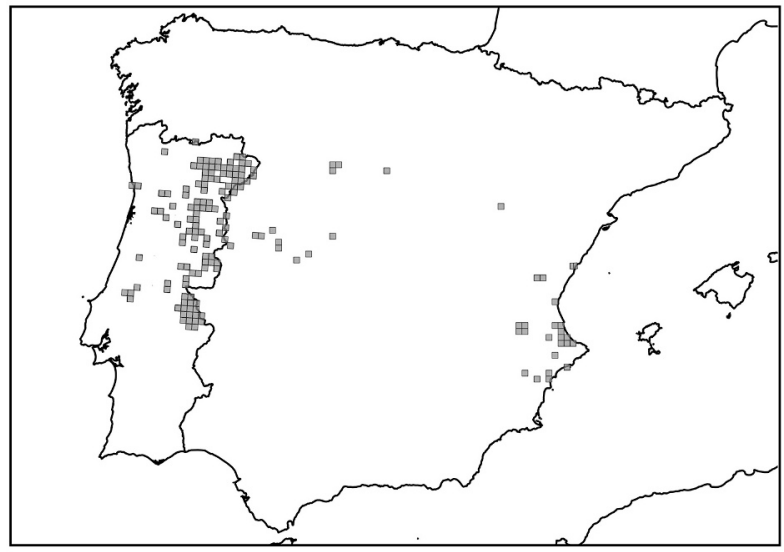

C) V-24 S8

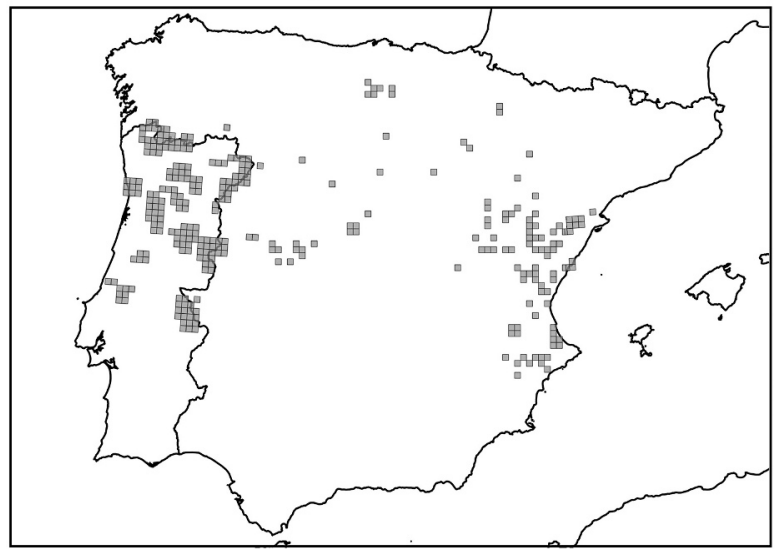

A
B) V-24 S9 and S7

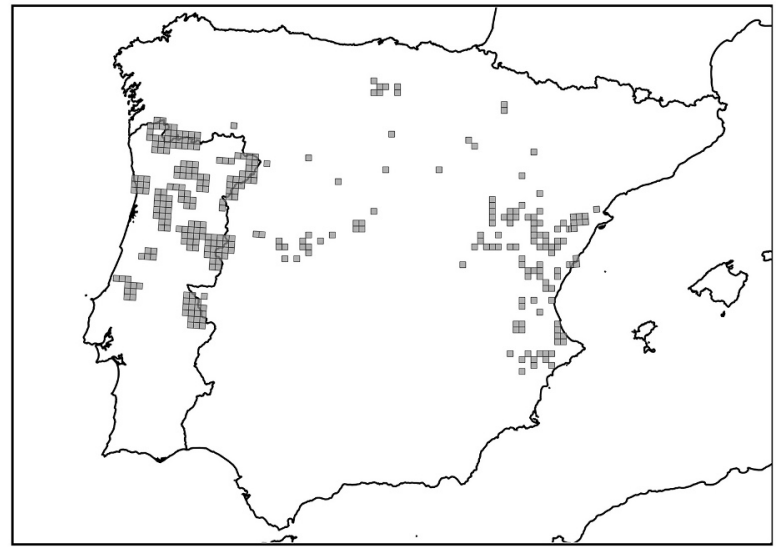

D) $\mathrm{V}-25$

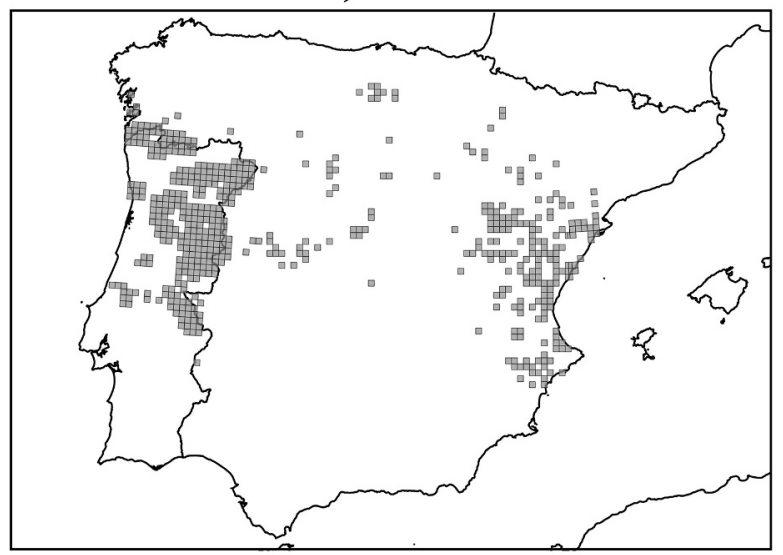

$250 \mathrm{~km}$

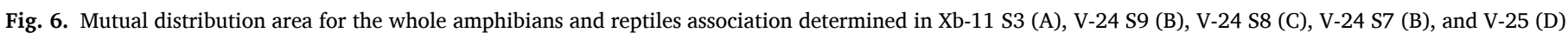

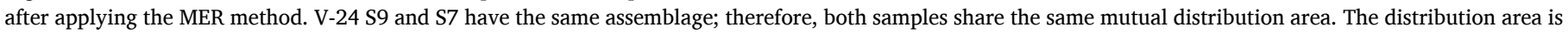

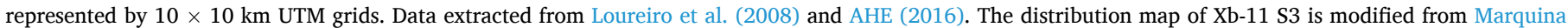
et al. (2017). 
to the current one at El Salt, with little variation in the bioclimatic parameters. Based on our results, the climate was slightly cooler (from -0.87 to $-1.3^{\circ} \mathrm{C}$ ) and more humid (from +305.31 to $+137.5 \mathrm{~mm}$ ) than the present climate (Table 4). Thus, the highest differences in MAT have been obtained in samples V-24 S7 and V-24 S9 $\left(-1.3{ }^{\circ} \mathrm{C}\right)$. The other temperature parameters (MinTC and MaxTW) show the same pattern as MAT. Both MaxTW and MinTC are slightly lower than today. Mean MaxTW values range from $27.19{ }^{\circ} \mathrm{C}$ in V-24 S8 to $27.64{ }^{\circ} \mathrm{C}$ in $\mathrm{V}-25$, whereas mean MinTC values oscillate between $0.98{ }^{\circ} \mathrm{C}$ in V-24 S7 or V24 S9 and $1.74{ }^{\circ} \mathrm{C}$ in V-24 S8 (Table 4).

Rainfall parameters show strong differences from their current average values in Alcoi. MAP values are higher than today in all samples (differences range from $+137.5 \mathrm{~mm}$ in V-24 S7 and V-24 S9 to +305.31 $\mathrm{mm}$ in $\mathrm{V}-24 \mathrm{~S} 8$ ) (Table 4). A similar trend is apparent for PWM, with the highest differences recorded in V-24 S8 (PWM: $+44.13 \mathrm{~mm}$ ) and the lowest differences recorded in V-24 S7 and V-24 S9 $(+18.98 \mathrm{~mm})$. As for PDM, samples V-24 S7 and V-24 S9 have yielded the highest difference $(+3.25 \mathrm{~mm})$, whereas the lowest difference $(+1.37 \mathrm{~mm})$ is obtained at V-24 S8.

\subsection{Thermoclimatic belts/vegetation stages}

When we overlap the areas of the Iberian Peninsula where the distribution of the species identified in SU Xb and V of El Salt are currently occurs with the map of the vegetation series of Spain (Rivas-Martínez, 1987), we observe that the dominant thermoclimatic belts represented in the surrounding area of El Salt in both SUs were, mesomediterranean (results vary from 62.78 to $49.03 \%$ ) and supramediterranean (45.72 to $31.34 \%$ ) (Table 5). The mesomediterranean belt is characterised by the

Table 4

Values of the climatic parameters estimated using the MER methodology.

\begin{tabular}{|c|c|c|c|c|c|c|}
\hline & & MEAN & $\sigma$ & MAX & MIN & $\Delta$ \\
\hline \multirow[t]{6}{*}{ F25 } & MAT & 12.77 & 2.47 & 18.4 & 4 & $-0,87$ \\
\hline & MaxTW & 27,64 & 2.51 & 34 & 19.4 & -0.85 \\
\hline & MinTC & 1.44 & 2.84 & 8.1 & -7 & -0.25 \\
\hline & MAP & 692.53 & 303.89 & 1798 & 276 & 148.95 \\
\hline & PWM & 95.69 & 46.34 & 273 & 41 & 21.42 \\
\hline & PDM & 17.62 & 8.7 & 50 & 3 & 2.31 \\
\hline \multirow[t]{6}{*}{ F24-S7 } & MAT & 12.34 & 2.62 & 18.3 & 4 & -1.3 \\
\hline & MaxTW & 27.23 & 2.49 & 34 & 19.4 & -1.26 \\
\hline & MinTC & 0.98 & 2.91 & 7.8 & -7 & -0.71 \\
\hline & MAP & 681.08 & 292.31 & 1798 & 312 & 137.5 \\
\hline & PWM & 93.25 & 43.28 & 272 & 41 & 18.98 \\
\hline & PDM & 18.56 & 9.06 & 48 & 4 & 3.25 \\
\hline \multirow[t]{6}{*}{ F24-S8 } & MAT & 12.61 & 2.38 & 18.2 & 4.1 & $-1,03$ \\
\hline & MaxTW & 27.19 & 2.53 & 33.6 & 19.4 & -1.3 \\
\hline & MinTC & 1.74 & 2.7 & 7.8 & -6.7 & 0.05 \\
\hline & MAP & 848.89 & 331.03 & 1798 & 357 & 305.31 \\
\hline & PWM & 118.4 & 50.46 & 272 & 42 & 44.13 \\
\hline & PDM & 16.68 & 8.8 & 47 & 5 & 1.37 \\
\hline \multirow[t]{6}{*}{ F24-S9 } & MAT & 12.34 & 2.62 & 18.3 & 4 & -1.3 \\
\hline & MaxTW & 27.23 & 2.49 & 34 & 19.4 & -1.26 \\
\hline & MinTC & 0.98 & 2.91 & 7.8 & -7 & -0.71 \\
\hline & MAP & 681.08 & 292.31 & 1798 & 312 & 137.5 \\
\hline & PWM & 93.25 & 43.28 & 272 & 41 & 18.98 \\
\hline & PDM & 18.56 & 9.06 & 48 & 4 & 3.25 \\
\hline \multirow[t]{6}{*}{ ALCOY } & MAT & 13.64 & & & & \\
\hline & MaxTW & 28.49 & & & & \\
\hline & MinTC & 1.69 & & & & \\
\hline & MAP & 543.58 & & & & \\
\hline & PWM & 74.27 & & & & \\
\hline & PDM & 15.31 & & & & \\
\hline
\end{tabular}

MAT (mean annual temperature, ${ }^{\circ} \mathrm{C}$ ); MaxTW (maximum temperature of the warmest month, ${ }^{\circ} \mathrm{C}$ ); MinTC (minimum temperature of the coldest month, ${ }^{\circ} \mathrm{C}$ ); MAP (mean annual precipitation, mm); PWM (mean rainfall of the wettest month, mm); PDM (mean rainfall of the driest month, mm); ALCOI (current situation). $\sigma$ (standard deviation of obtained values); $\Delta$ (difference between the values obtained from the fossil assemblages of El Salt and current values in Alcoi).
Table 5

Percentage values of thermoclimatic belts (\%) inferred from the assemblages of fossil amphibians and reptiles analysed in Stratigraphic Units $\mathrm{Xb}$ and Upper V at El Salt.

\begin{tabular}{llllll}
\hline & Xb-11 S3 & V-24 S9 & V-24 S8 & V-24 S7 & V-25 \\
\hline Alpine & 0.00 & 0.00 & 0.00 & 0.00 & 0.00 \\
Subalpine & 0.00 & 0.00 & 0.00 & 0.00 & 0.00 \\
Montane & 0.00 & 2.10 & 0.87 & 2.10 & 1.34 \\
Coline & 0.00 & 2.25 & 1.03 & 2.25 & 3.61 \\
Cryoromediterranean & 0.00 & 0.00 & 0.00 & 0.00 & 0.00 \\
Oromediterranean & 0.14 & 0.30 & 0.25 & 0.30 & 0.26 \\
Supramediterranean & 31.34 & 45.08 & 38.71 & 45.08 & 40.68 \\
Mesomediterranean & 62.78 & 49.03 & 58.29 & 49.03 & 52.70 \\
Thermomediterranean & 5.73 & 1.23 & 0.85 & 1.23 & 1.42 \\
\hline
\end{tabular}

following thermicity indexes: mean annual temperature (MAT): 13-17 ${ }^{\circ} \mathrm{C}$; average of the minimum temperatures of the coldest month (m): $1-4{ }^{\circ} \mathrm{C}$; average of the maximum temperatures of the coldest month (M): $9-14^{\circ} \mathrm{C}$ ). The supramediterranean belt is characterised by MAT: 8-13 ${ }^{\circ} \mathrm{C}$; m: $1-4{ }^{\circ} \mathrm{C}$; M: $2-9{ }^{\circ} \mathrm{C}$ (Rivas-Martínez, 1987). The results show a clear evolution between $\mathrm{Xb}-11 \mathrm{~S} 3$ and $\mathrm{V}-25$ with a progressive increase in the presence of the supramediterranean thermoclimatic belt, although it never surpases mesomediterranean belt values. Sample V-24 $S 8$ records a peak of the represativeness of the mesomediterranean belt and a fall in the supramediterranean percentage (Table 5).

\section{Discussion}

\subsection{Herpetofaunal assemblage}

In accordance with the SIARE program (AHE, 2016), the current community of herpetofauna present in the UTM square $10 \times 10$ $30 \mathrm{SYH} 18$ (where the archaeological site of El Salt is located) is composed of the following species: one newt (Pleurodeles walt), five anurans (Pelodytes hespericus, Alytes obstetricans, Epidalea calamita, Bufo spinosus, and Pelophylax perezi), six lizards (Tarentola mauritanica, Blanus rufus, Chalcides bedriagai, Psammodromus algirus, Podarcis hispanicus, and Timon nevadensis) and six snakes (Coronella girondica, Hemorrhois hippocrepis, Zamenis scalaris, Natrix maura, Malpolon monspessulanus, and Vipera latastei). The only turtle species recorded is Trachemys scripta, a North American species recently introduced in the Iberian Peninsula, at the end of the 20th century (Pérez-Santigosa et al., 2008). All of the species described in this work are present today in the study area. This stability in the association of amphibians and reptiles is common in numerous archaeo-palaeontological sites from MIS 3 to MIS 1 in the centre and south of the Iberian Peninsula (Bisbal-Chinesta and Blain, 2018). The major changes in the communities of amphibians and reptiles in the southeast of the Iberian Peninsula in the latest 40,000 years were the extirpation of Testudo (Chersine) hermanni (Morales Pérez and Sanchis Serra, 2009) and the anthropic introduction during historical times of species such as Chamaeleo chameleon (Paulo et al., 2002), Testudo graeca (Álvarez et al., 2000), and Chalcides ocellatus (Bisbal-Chinesta et al., 2020b). Conversely, the record of small mammals from the SU V yielded species currently absent in the area, such as Arvicola sapidus, Microtus arvalis, Microtus (Iberomys) cabrerae, and Talpa occidentalis (Fagoaga et al., 2019), thus reflecting that amphibians, reptiles and at least some small mammals show different responses to environmental change scenarios.

Previous research with fossil amphibians and reptiles in the El Salt site have reported the presence in SU Xb of three taxa of anurans (Alytes obstetricans, Bufo bufo s.l., and Epidalea calamita), one tortoise (Testudo [Chersine] hermanni), one blanid (Blanus cinereus s.l.), two lizards (Chalcides bedriagai and cf. Acanthodactylus erythrurus), and one snake (cf. Zamenis scalaris) (Morales Pérez and Sanchis Serra, 2009; Marquina et al., 2017). When compared with the faunal list of SU V, the largest difference is the absence in SU V of the most marked termophilous taxa 
(Testudo [Chersine] hermanni and Blanus cinereus s.1.) and the disappearance of Bufo bufo s.l., a species that inhabits a wide range of habitats in Europe, North Africa, and western Asia. The only environmental requirement of Bufo bufo seems to be the presence of quiet or low-energy and preferably permanent water bodies with vegetation during its breeding season (Lizana, 2002). Thus, the faunal composition of the recovered assemblages in Units $\mathrm{Xb}$ and $\mathrm{V}$ shows a strong conservative character, only perturbed by a probable climatic fluctuation, reflected primarily in the relative abundance of the different taxa of the palaeocommunity in the time span represented between Units $\mathrm{Xb}(52.3 \pm 4.6$ ka) and $V(44.7 \pm 3.2 \mathrm{ka})$. However, it is not clear whether the extinction of $T$. (C.) hermanni was the result of climate change (Morales Pérez and Sanchis Serra, 2009), human over-exploitation (Nabais and Zilhão, 2019) or a synergy of both. This stability in the herpetofaunal community is also generally present in other contemporaneous sites. Thus, the determined taxa of amphibians and reptiles are all currently present in Cova dels Xaragalls (López-García et al., 2012b), Cova del Gegant (López-García et al., 2012c), Cova Eirós (Rey-Rodríguez et al., 2016) and Lezetxiki II Cave (Garcia-Ibaibarriaga et al., 2018). In other sites (such as Abric Romaní, Canyars, or Teixoneres in northeastern Spain), some identified taxa are not present in the region. Thus, the absence of the species Rana temporaria, Coronella austriaca, and Vipera aspis is related to the southward shift of the distribution area of that taxa during the Late Pleistocene and a posterior regression (Burjachs et al., 2012; LópezGarcía et al., 2013, 2014). A similar case is the presence in Cueva del Boquete de Zafarraya of $C$. austriaca (Barroso Ruiz and Bailon, 2003), a Eurosiberian species with relict populations in the south of the Iberian Peninsula related to the alternation of climatic phases during the Quaternary (Santos et al., 2008). Barroso Ruiz and Bailon (2003) also note the presence of remains belonging to Testudo sp., whose absence in the region is discussed above. Finally, in Gorham's Cave, the current absence of Lissotriton sp., Alytes sp., and T. (C.) hermanni may be related to the disturbance caused by the human occupation of the territory (Blain et al., 2013). Although Blain et al. (2013) point out that Triturus cf. pygmaeus, Discoglossus sp., Acanthodactylus erythrurus, and Natrix maura are absent in Gibraltar, all of these taxa are present today in that region (AHE, 2016).

\subsection{Habitat reconstruction}

The increasing importance of Open Dry and Rocky habitats observed in SU V probably indicates a more arid environment. The herpetofaunabased palaeoenvironmental reconstruction of SU Xb F11-S3, dated as $52.3 \pm 4.6 \mathrm{ka}$, shows a landscape composed of bushland and forest patches, in which some open areas were present (Marquina et al., 2017). These results suggest a turnover in the dominant habitat-type from Woodland to Open Dry at the end of the Middle Palaeolithic in the surroundings of Alcoi (Fig. 6). The reconstruction based on the fossil small mammal assemblages points to a similar scenario, with a substantial increase in Open Dry habitats (from Units Xb to Upper V), although open forests were still prevalent (Fagoaga et al., 2019). The study of anthracological remains from El Salt, conducted by VidalMatutano (2016), describes a forest clearly dominated by Pinus nigrasylvestris during the Middle Palaeolithic (reaching 79.89\% of all woody taxa remains in SU V-24). These pine trees are cryophilous species currently present in medium-high Mediterranean mountains. At SU V, a slight increase in Juniperus sp. has been interpreted as indicating a trend to colder and drier palaeoclimatic conditions (Vidal-Matutano, 2016). In summary, herpetofauna, small mammals, and charcoal all suggest a tendency towards more open and drier conditions towards the upper part of the sequence.

The dominance of forested landscapes has been reported in numerous Iberian MIS 3 archaeological sites, such as Cueva del Boquete de Zafarraya (Barroso Ruiz and Bailon, 2003; Barroso Ruiz et al., 2003), Cueva del Conde (López-García et al., 2011a), Gorham's Cave (LópezGarcía et al., 2011b), Cova dels Xaragalls (López-García et al., 2012a, 2012b, 2012c), Teixoneres (López-García et al., 2014), Canyars (LópezGarcía et al., 2014), Cova del Gegant (López-García et al., 2014), L’Arbreda Cave (López-García et al., 2015), Cova Eirós (Rey-Rodríguez et al., 2016), Lezetxiki II Cave (Garcia-Ibaibarriaga et al., 2018), and Abric Romaní (Fernández-García et al., 2018, 2020). Nevertheless, the aridification trend has also been reported in other contemporaneous Iberian sites, including the Gorham's Cave (Blain et al., 2013), L'Arbreda Cave (López-García et al., 2015), and Abric Romaní (Fernández-García et al., 2018).

The application of the HWM to small vertebrates' assemblages from various northeastern Spain localities shows that, during MIS 3, the regional landscape was dominated by open-forest formations regardless of climatic fluctuations (López-García et al., 2014). In contrast to northeastern Spain sites (Cova de L'Arbreda, Teixoneres, Abric Romaní, Cova del Gegant, Canyars and Cova del Xaragalls) the results at El Salt (southeastern Iberia) indicate a greater presence of open habitats (Marquina et al., 2017; Fagoaga et al., 2018, 2019; this work) (Fig. 7). This discrepancy may be related to the groups included in the palaeoenvironmental reconstructions. As shown in Fig. 7, reconstructions based exclusively on mammals (Fernández-García et al., 2018, 2020; Fagoaga et al., 2019) yield higher forest values than those based on herpetofauna (Marquina et al., 2017; this work). In sites where HWM was applied to both faunas (amphibians and reptiles and small mammals), more balanced results are obtained between both types of habitats, albeit always with predominant forests (López-García et al., 2011b, 2012a, 2012b, 2012c, 2014, 2015). The Canyars site constitutes a special case: the assemblage of small vertebrates suggests a landscape with an important component of open habitats (López-García et al., 2014). However, this may stem from the influence of colder and more arid conditions during HE 4 (Daura et al., 2013) or from a predominance of amphibians and reptiles (MNI: 14 individuals) over mammals (MNI: 11) and the resulting bias in the HWM calculations (see López-García et al., 2014). In general, the Iberian amphibians and reptiles of the Mediterranean bioregion have a wide distribution area (Sillero et al., 2009). The different taxa show high ecological plasticity, allowing them to occupy a diverse range of habitats (Sillero et al., 2009). At a small scale, they only select those areas that accomplish specific conditions; for example, humid and cool microhabitats are essential for the survival of many amphibian species due to their high water dependence (Boone et al., 2003). However, the defined habitat groups are too generalised to consider these microhabitat preferences, which results in biased results. This discrepancy may also result from the particular geographic location of El Salt, as compared to the other sites. This is related to the marked climatic gradient in the Iberian Peninsula, with a clear rainfall decrease from north to south and from west to east (Ninyerola et al., 2005). In fact, high-resolution pollen analyses from lacustrine sequences in the east of Spain, covering from MIS 5 to MIS 1, demonstrated that the arboreal cover was always higher in the north than in the south (Burjachs et al., 1996).

\subsection{Thermoclimatic belts/vegetation stages}

A thermoclimatic belt is composed of areas that share rainfall and temperature conditions and similar plant communities (Rivas-Martínez, 1987). Vegetation responds to climate change modifying its distribution area (Turner and Hannon, 1988). Therefore, the study of the fossil assemblages of reptiles and amphibians, along with the comparison to the current herpetofauna, may shed light on these distributional changes. Relating the overlapping distribution area to the vegetation maps series of Spain (Rivas-Martínez, 1987) allows for the determination of the regional dominant thermoclimatic belt in the past.

Currently, the Spanish inland territory is divided into two bioregions: the Eurosiberian region, which is limited to the north of the Iberian Peninsula, and the Mediterranean region, which accounts for the rest of the territory (Rivas-Martínez, 1987). According to Rivas-Martínez (1987), the Mediterranean region occupies $84.70 \%$ of the territory, 


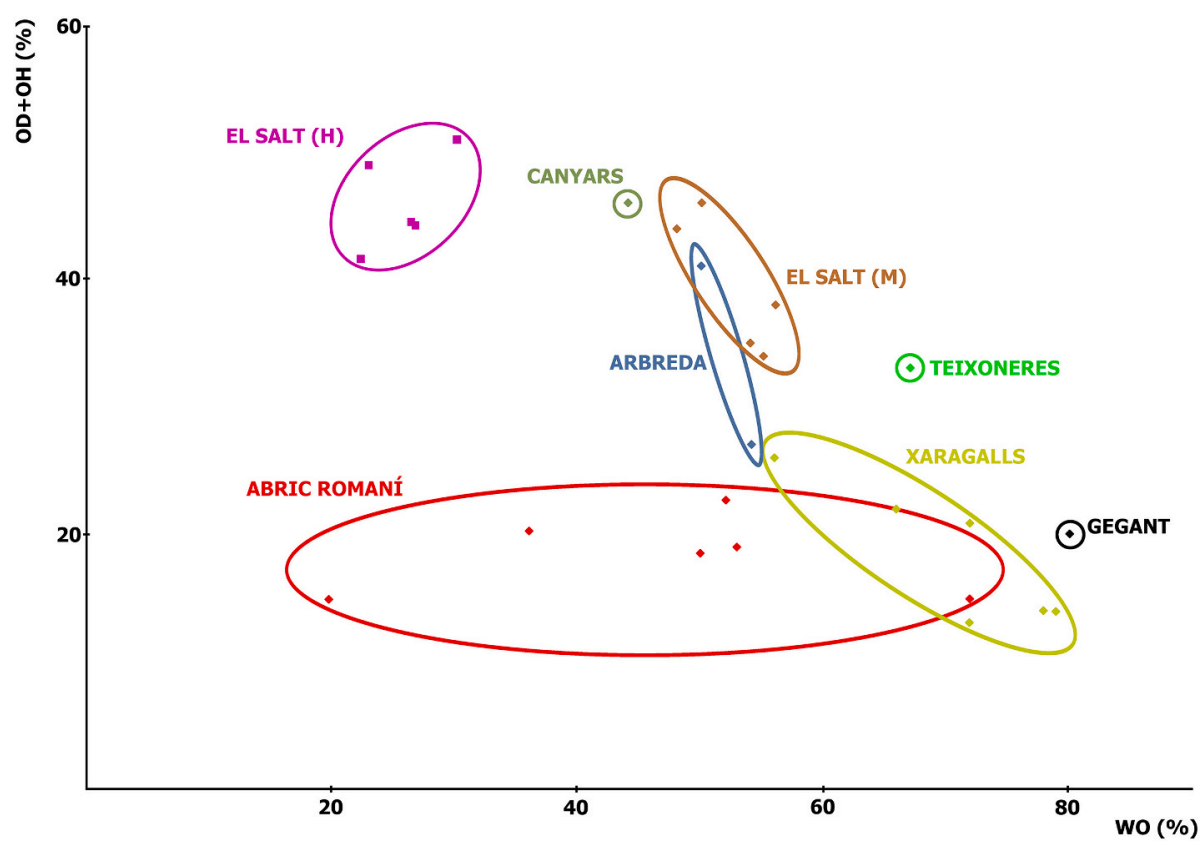

Fig. 7. Representation of Woodland (WO) and open habitats types (OD $+\mathrm{OH}$, the sum of Open Dry and Open Humid habitats) based on the palaeoenvironmental reconstruction in different sites of eastern Spain. The different points represent the levels and units of each site. From North to South: Cova de L'Arbreda (López-García et al., 2015); Teixoneres (López-García et al., 2014); Abric Romaní (Fernández-García et al., 2018, 2020); Cova del Gegant (López-García et al., 2014); Canyars (LópezGarcía et al., 2014), Cova dels Xaragalls (López-García et al., 2012a, 2012b, 2012c) and El Salt (Fagoaga, 2019) for small mammals (M) and herpetofauna (H) (this work).

whereas the Eurosiberian region represents only $15.30 \%$ of inland Spain. Following the different stages within the Mediterranean region, the mesomediterranean belt is represented in $42.49 \%$ of the current inland Spanish territory, whereas the supramediterranean belt occupies 29.19\% (Table 6). At present, the mesomediterranean stage is predominant in the Alcoi region, whereas the supramediterranean is restricted to higher areas, such as the Font Roja Natural Park (Fagoaga et al., 2018), located $1000 \mathrm{~m}$ in altitude. The studied fossil assemblages show the dominance of mesomediterranean conditions, albeit with a strong representation of the supramediterranean stage in V-24. These results may be explained by the current distribution of each species described in the work, mostly recorded in the mesomediterranean stage and to a lesser extent in the supramediterranean (Table 7); alternatively, both stages are the current dominant thermoclimatic belts in Spanish territory. Regarding the first point, in the Eurosiberian region, the most represented belts in the distribution of the studied species are the montane and coline belts, which show bioclimatic parameters equivalent to the supra- and mesomediterranean belts of the Mediterranean region (Table 6).

The small mammal associations of the same SU yield different results: in $\mathrm{SU} \mathrm{Xb}$, the dominant stage is clearly the supramediterranean, whereas in SU V, it is the mesomediterranean (Fagoaga et al., 2018, 2019). Differences between herpetofauna and small mammals are related to the wide distribution of the common area of amphibian and reptile species (mainly east and west of the Iberian Peninsula), as opposed to the much more restricted distribution of mammals (north and northwest). The study of charcoal from SU Xb (Vidal-Matutano et al., 2018) and SU V (Vidal-Matutano, 2016) reveals that the supramediterranean was the dominant stage during the Middle Palaeolithic in El Salt's surrounding area, as in other Iberian localities (Vidal-Matutano, 2018). The differences recorded between this proxy and the results obtained from the study of small vertebrate associations may stem from a different area of the home range of humans and the accumulation agent of small vertebrates (in this case, Bubo bubo).

\subsection{Palaeoclimatic reconstruction}

Regarding temperatures, the palaeoclimatic reconstruction suggests a context with lower temperatures in the younger unit (SU V) than in the older one (SU Xb). Differences of values obtained between the oldest sample (SU Xb) and more modern samples (SU V) range between $-1.66{ }^{\circ} \mathrm{C}\left(\mathrm{V} 24-\mathrm{S} 9\right.$ and V24-S7) and $-1.23^{\circ} \mathrm{C}$ (V25) (Fig. 8). During the time span considered, rainfall experienced the opposite trend than the latter case. Thus, MAP, PWM, and PDM show lower values from SU Xb than in SU V. This scenario in modern units of more rainfall is not congruent with the results obtained in the palaeoecological reconstruction (major representation of open habitats in SU V). The results obtained show a high standard deviation (Table 4), due to the wide geographical range reached by the mutual distribution area (Fig. 6). As a result, the set of data used for the calculation of the palaeoclimatic parameters show a strong data dispersion (i.e., $\mathrm{MAP}_{\max }=1798 \mathrm{~mm}$ and $\mathrm{MAP}_{\text {min }}=276 \mathrm{~mm}$ in V-25) because the Iberian Peninsula is a highly mountainous region and that obtained mutual distribution area is formed by two differentiated areas: one in western Iberia and another in

Table 6

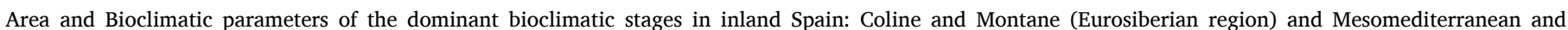
Supramediterranean belts (Mediterranean region).

\begin{tabular}{|c|c|c|c|c|c|c|c|c|c|}
\hline Region & BIOCLIMATIC BELT & $\mathrm{T}$ & M & M & It & $\mathrm{H}$ & Total (ha) & \% Spain & \% Region \\
\hline \multirow[t]{2}{*}{ Eurosiberian $(7,308,834.39$ ha) } & Montane & 12 to $6^{\circ} \mathrm{C}$ & 2 to $-4{ }^{\circ} \mathrm{C}$ & 10 to $3{ }^{\circ} \mathrm{C}$ & 240 to 50 & IX-VI & $3,785,771.87$ & 7.57 & $51.8 \%$ \\
\hline & Coline & $>12{ }^{\circ} \mathrm{C}$ & $>2{ }^{\circ} \mathrm{C}$ & $>10^{\circ} \mathrm{C}$ & $>240$ & XI-IV & $3,020,004.83$ & 6.04 & $41.3 \%$ \\
\hline \multirow[t]{2}{*}{ Mediterranean $(42,563,953.02$ ha) } & Supramediterranean & 13 to $8{ }^{\circ} \mathrm{C}$ & -1 to $-4{ }^{\circ} \mathrm{C}$ & 9 to $2{ }^{\circ} \mathrm{C}$ & 210 to 60 & IX-VI & $14,595,158.33$ & 29.19 & $34.2 \%$ \\
\hline & Mesomediterranean & 17 to $13^{\circ} \mathrm{C}$ & 4 to $-1{ }^{\circ} \mathrm{C}$ & 14 to $9{ }^{\circ} \mathrm{C}$ & 350 to 210 & X-IV & $21,245,402.84$ & 42.49 & $49.9 \%$ \\
\hline
\end{tabular}

Total area of Spain $\left(50 \times 10^{6}\right.$ ha $)$

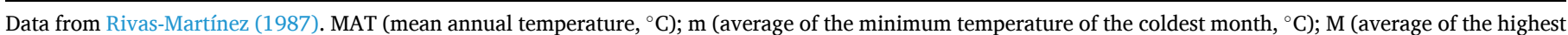

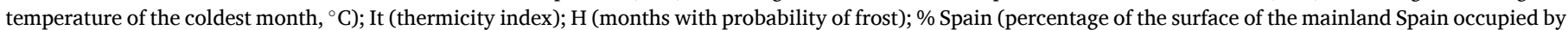
the bioclimatic belt); \% Region (percentage of its respective bioregion occupied by the bioclimatic belt). 
Table 7

Representation (\%) of the different thermoclimatic belts in the current distribution of the species recorded in the fossil association.

\begin{tabular}{|c|c|c|c|c|c|c|c|}
\hline & Alytes obstetricans & Bufo bufo s.l. & Epidalea calamita & Blanus cinereus s.l. & Chalcides bedriagai & Natrix maura & Vipera latastei \\
\hline Alpine & 0.02 & 0.00 & 0.00 & 0.00 & 0.00 & 0.01 & 0.00 \\
\hline Subalpine & 0.38 & 0.00 & 0.04 & 0.00 & 0.00 & 0.13 & 0.04 \\
\hline Montane & 4.84 & 0.00 & 1.37 & 0.00 & 0.21 & 2.09 & 1.26 \\
\hline Coline & 4.98 & 0.00 & 1.30 & 0.00 & 0.69 & 1.76 & 0.57 \\
\hline Cryoromediterranean & 0.00 & 0.00 & 0.00 & 0.00 & 0.00 & 0.00 & 0.00 \\
\hline Oromediterranean & 0.14 & 0.09 & 0.09 & 0.09 & 0.24 & 0.10 & 0.26 \\
\hline Supramediterranean & 39.12 & 11.60 & 26.07 & 11.60 & 23.53 & 25.74 & 40.86 \\
\hline Mesomediterranean & 49.87 & 79.23 & 68.12 & 79.23 & 69.01 & 66.62 & 54.65 \\
\hline Thermomediterranean & 0.65 & 9.08 & 3.00 & 9.08 & 6.32 & 3.56 & 2.37 \\
\hline
\end{tabular}
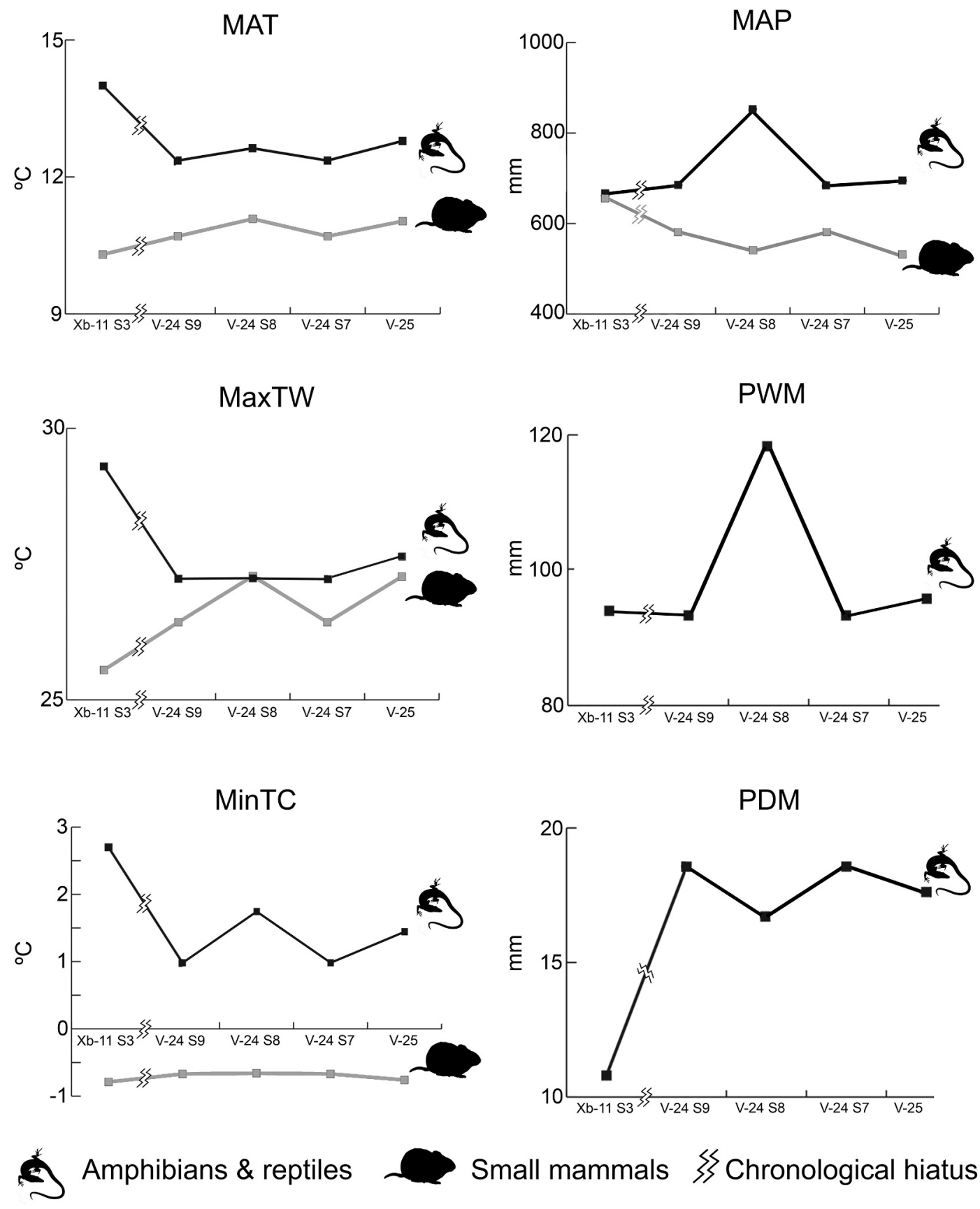

Small mammals \$Chronological hiatus

Fig. 8. Evolution of the bioclimatic parameters after the application of the MER method to the fossil assemblages of herpetofauna and small mammals from Stratigraphic Units Xb and V of El Salt. MAT (mean annual temperature, ${ }^{\circ} \mathrm{C}$ ); MaxTW (maximum temperature of the warmest month, ${ }^{\circ} \mathrm{C}$ ); MinTC (minimum temperature of the coldest month, ${ }^{\circ} \mathrm{C}$ ); MAP (mean annual precipitation, mm); PWM (mean rainfall of the wettest month, mm); PDM (mean rainfall of the driest month, mm). 
the east of Spain.

The palaeoclimatic analysis based on small mammals, developed by Fagoaga et al. (2019) in the same levels of El Salt, points to conditions wetter and cooler than those prevailing today. In constrast to our results based on herpetofauna, the temperature parameters provided by Fagoaga et al. (2019), based on small mammals, show higher MAT, MaxTW, and MinTC for the youngest bed (SU V) than for the older Xb-11 S3. For all calculated parameters, the resulting absolute values based on small mammals are lower than those based on the assemblages of amphibians and reptiles (Fig. 8). These differences are related to the current mutual distribution area obtained in each case. The presence of mammal species such as Microtus arvalis (present in all of the SUs and surfaces studied) and the punctual record of Talpa occidentalis (only recorded in sample V24-S9) restrict the distribution to the northwestern quadrant of the Iberian Peninsula (Fagoaga et al., 2018, 2019), whereas the common distribution of amphibians and reptiles is located in medial latitudes in the East and West of the Iberian Peninsula, both in SU Xb and SU V (Marquina et al., 2017; present work). Fagoaga et al. (2019) propose that the climatic parameters obtained for SU V should be placed between values considered for cold and temperate stages, although nearer to temperate ones.

The separate application of the MER method to the association of small mammals (López-García et al., 2011b) and the herpetofauna (Blain et al., 2013) in Gorham's Cave yields a difference in results similar to our case. Thus, at level IV of this locality, the analysis based on the small mammal assemblage resulted in a lower MAT $\left(-4.2{ }^{\circ} \mathrm{C}\right)$ and a higher MAP $(+61.4 \mathrm{~mm})$ than the analysis based on amphibians and reptiles (López-García et al., 2011b; Blain et al., 2013). This difference is explained by the presence of two shrews, Sorex minutus and Sorex gr. coronatus-araneus, which currently live in northern Spain (Blain et al., 2013). Thus, based on all of these results, herpetofauna seem to provide higher temperatures than small mammals. As for rainfall, the difference in the results may be related to the extension of the species distribution. Therefore, in theory, the presence of a taxon with a restricted distribution would result in a geographically more limited common area and in less-dispersed climatic results. Another possibility is the existence in the assemblage of a high number of taxa, which is true of the palaeoclimatic reconstruction of level IV at Gorham's Cave, based on the herpetofaunal assemblage (Blain et al., 2013).

Overall, our results in this study and those obtained for other contemporaneous eastern Iberian sites (L'Arbreda Cave, Teixoneres, Abric Romaní, Canyars, and Cova dels Xaragalls) reveal that the

Table 8

MAT and MAP values obtained using the MER methodology from Eastern Iberian sites contemporaneous to El Salt.

\begin{tabular}{|c|c|c|c|c|c|c|}
\hline Site & Level & Age (ka) & $\begin{array}{l}\text { MAT } \\
\left({ }^{\circ} \mathrm{C}\right)\end{array}$ & $\begin{array}{l}\text { MAP } \\
(\mathrm{mm})\end{array}$ & $\begin{array}{l}\triangle \mathrm{MAT} \\
\left({ }^{\circ} \mathrm{C}\right)\end{array}$ & $\begin{array}{l}\triangle \mathrm{MAP} \\
(\mathrm{mm})\end{array}$ \\
\hline \multirow{2}{*}{$\begin{array}{l}\text { Cova de } \\
\text { L'Arbreda }\end{array}$} & $\mathrm{H}$ & $41.64-38.29$ & 8.4 & 950 & -6.70 & +142 \\
\hline & I & $45.84-41.41$ & 6 & 1500 & -9.10 & +692 \\
\hline \multirow{5}{*}{$\begin{array}{l}\text { Abric } \\
\text { Romaní }\end{array}$} & $\mathrm{D}$ & $45.6-44.4$ & 11.6 & 981 & -3.70 & 322 \\
\hline & $\mathrm{E}$ & 49 & 9.7 & 950 & -5.60 & 291 \\
\hline & $\mathrm{J}$ & $50.4-49.3$ & 9.9 & 719 & -5.40 & 60 \\
\hline & $\mathrm{N}$ & 54.5 & 12.2 & 925 & -3.10 & 266 \\
\hline & $\mathrm{O}$ & 54.2 & 11.1 & 840 & -4.20 & 181 \\
\hline \multirow{8}{*}{$\begin{array}{l}\text { Canyars } \\
\text { Teixoneres } \\
\text { Cova dels } \\
\text { Xaragalls }\end{array}$} & - & 39.4 & 10.11 & 757.6 & -5.19 & 98.6 \\
\hline & II & $44.21-33.06$ & 7.6 & 1008 & -7.70 & 349 \\
\hline & C3 & & 7.92 & 1092 & -5.48 & 463 \\
\hline & $\mathrm{C} 4$ & $45.12-48.24$ & 8 & 925 & -5.40 & 296 \\
\hline & C5 & & 10.36 & 664 & -3.04 & 35 \\
\hline & C6 & $>43.5$ & 8 & 950 & -5.40 & 321 \\
\hline & C7 & & 8.67 & 900 & -4.73 & 271 \\
\hline & $\mathrm{C} 8$ & & 10.48 & 729 & -2.92 & 100 \\
\hline
\end{tabular}

From North to South: Cova de L'Arbreda (López-García et al., 2015); Teixoneres (López-García et al., 2014); Abric Romaní (López-García et al., 2014; FernándezGarcía et al., 2020); Canyars (López-García et al., 2014) and Cova dels Xaragalls (López-García et al., 2012a). $\triangle$ MAT and $\triangle$ MAP: differences between past and present MAT and MAP values. palaeoclimatic conditions were cooler and wetter than current conditions (Table 8). In the time interval considered, all of the Iberian sites show a clear trend towards a gradual fall of the MAT and MAP (LópezGarcía et al., 2012a, 2012b, 2012c, 2014, 2015; Fernández-García et al., 2020).

The differences between past and present MAT and MAP at a particular locality are difficult to interpret, since these parameters are influenced by the altitude (current and past) of the site and the effect of coastal tempering during the time period under consideration. For example, sea level does not appear to have risen above about $-60 \mathrm{~m}$ during MIS 3 on the Mediterranean French coast (Lambeck and Bard, 2000). Despite this possible bias, some similarities with present conditions can still be seen, such as the northernmost localities showing lower values of MAT and higher MAP than the southernmost localities.

The differences in MAT most similar to those at El Salt are shown in the Cova dels Xaragalls levels C5 $\left(-3.04{ }^{\circ} \mathrm{C}\right)$ and C8 $\left(-2.92{ }^{\circ} \mathrm{C}\right)$ and in the Abric Romaní level N $\left(-3.10^{\circ} \mathrm{C}\right.$ ) (López-García et al., 2012a, 2012b, 2012c; Fernández-García et al., 2020). As for the MAP results, the Cova dels Xaragalls level C8 $(+100 \mathrm{~mm})$ and the Cova de L'Arbreda level $\mathrm{H}$ $(+142 \mathrm{~mm})$ are the closest to the SU V of El Salt (López-García et al., 2012a, 2012b, 2012c, 2015). The Abric Romaní level $\mathrm{N}$ has been chronologically assigned to Insterstadial (IS) 16 (Burjachs et al., 2012); level C8 of Cova dels Xaragalls has been assigned to IS 15 or IS 16 (López-García et al., 2012a, 2012b, 2012c); and level H of Cova de L'Arbreda has been assigned to IS 10 (López-García et al., 2015). Based on these similarities, our palaeoclimatic reconstruction seems to indicate a cool and humid phase during MIS 3, which is congruent with the consideration of the interstadials as generally warm and wet moments, as opposed to the stadial periods, which are generally cold and dry (Sánchez Goñi et al., 2009). According to the proposed chronology (Galván et al., 2014a), Unit V may correlated to Interstadial 12 or 13.

The Iberian Peninsula presents a remarkable climatic diversity due to its mountainous topography and its location in middle latitudes. Iberian climate gradients are characterised by two clear trends: temperature rises from north to south and rainfall decreases from north to south and from west to east (Ninyerola et al., 2005). Similar trends are expected to have occurred during the Quaternary. In this sense, the overall palaeoclimatic reconstructions based on small vertebrates in eastern Spain seem to show a progressive positive trend in the MAT and a negative trend in the MAP from north to south (Fig. 9). The northernmost considered site, Cova de L'Arbreda, shows lower MAT and higher MAP than the rest of the localities, whereas El Salt represents the opposite situation.

\subsection{Implications for the last Neanderthals from El Salt}

The drier scenario inferred from the palaeoenvironmental reconstructions of the older (SU Xb) and younger units (on SU V) at El Salt may have had a negative impact on the human populations that inhabited the region. In this sense, the major concentration of human activity (archaeological remains, combustion residues, and abundant faunal remains associated with lithic tools) has been found in the interval represented by SU XII to IX (Galván et al., 2014a), in which the assemblages of small vertebrates indicate humid conditions with dominant forest formations (SU Xb) (Marquina et al., 2017; Fagoaga et al., 2018, 2019) in a supramediterranean sub-humid context (VidalMatutano et al., 2018). The record of SU V reveals a change in depositional dynamics from gravitational to wind sedimentation and an increase in the episodes of roof collapse (Gómez de la Rúa et al., 2010). Both events, which occurred after the final abandonment of the site (Mallol et al., 2012), may be related to colder climatic conditions. Thus, aeolian sedimentation has been related to an increase in wind intensity in the Mediterranean area, due to changes in atmospheric circulation over the North Atlantic region during the D/O stadials and HE (Moreno et al., 2002). Moreover, the disaggregation of the travertine, limestone bedrock, along with n-alkane chain analyses, is consistent with a dry or 


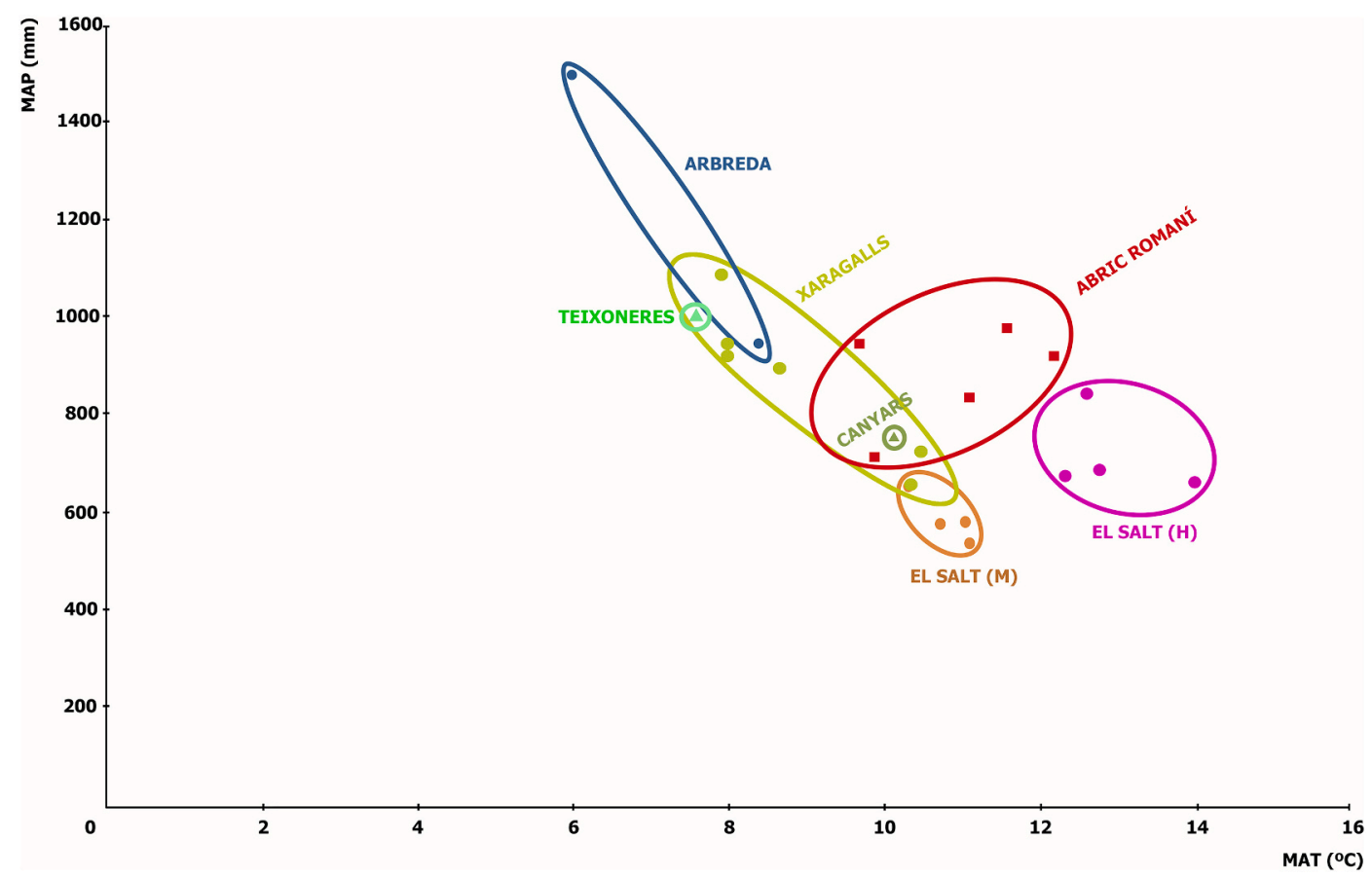

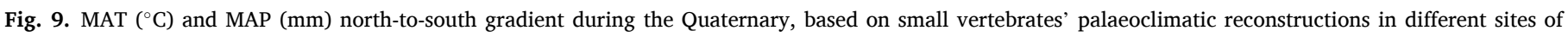

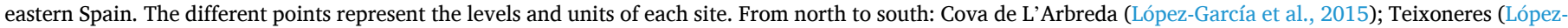

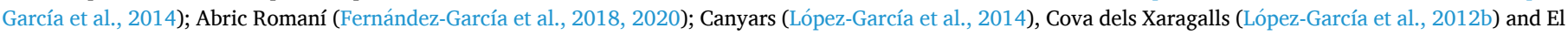
Salt (Fagoaga et al., 2018, 2019) based on small mammals (M) and herpetofauna (H) (this work).

semi-dry climatic context with a prevalence of herbaceous species (Galván et al., 2014a). TL dating of the roof collapse at the base of SU V, in addition to OSL dating obtained for its middle part, places this segment between HE 5 and HE 4 (Galván et al., 2014a). In contrast to the lower units, upper SUs (VIII to VI) present very few, smaller, and thinner combustion structures and significantly smaller faunal and lithic assemblages (Galván et al., 2014a). In other words, the archaeological record of El Salt points to a sudden extirpation of the Neanderthals in a context of an environmental aridification. Latter on, after an occupational hiatus, the territory was once again occupied by an indeterminate group of humans (Galván et al., 2014a). A similar pattern has been observed in other Iberian sites (Mallol et al., 2012).

\section{Conclusions}

The conclusions obtained from the study of the assemblage of fossil amphibians and reptiles from SU V at El Salt are as follows:

- The herpetofaunal assemblage of SU V ( $44.7 \pm 3.2 \mathrm{ka})$ is composed of three anurans (Pelodytes sp., Alytes obstetricans, and Epidalea calamita), two lizards (Lacertidae indet. and Chalcides bedriagai) and five snakes (Colubridae indet., Coronella sp., Coronella sp. or Zamenis sp., Natrix maura, and Vipera latastei). These taxa have been recovered from all the studied samples, except Natrix maura, which is found exclusively in V-24 S8, and Pelodytes sp. and Coronella sp. or Zamenis sp., which are found only in V24-S9. As for Xb11-S3 (SU Xb; $52.3 \pm$ $4.6 \mathrm{ka}$ ), the only difference is the absence of Testudo (Chersine) hermanni, Blanus cinereus s. 1., and Bufo bufo s. 1 .

- All of the species recorded in SU V at El Salt are currently present in the Mediterranean bioregion, although some taxa are not exclusive to it. Currently, all of the identified species of amphibians and reptiles are extant in the surrounding area.

- According to the proposed palaeoecological reconstruction, the landscape in the surrounding area of El Salt around $44.7 \pm 3.2-45.2$ \pm 3.4 ka (SU V) would have been dominated by open dry habitats throughout the studied sequence (V24-S9, V-24 S8, V-24-S7, and V25). The representation of this habitat is higher in the modern samples (SU V), whereas in SU Xb (52.3 $\pm 4.6 \mathrm{ka})$, forest habitat was the dominant habitat type.

- Our results indicate the dominance in the region of the mesomediterranean thermoclimatic belt in both SU Xb and SU V. These results are not coincident at all with other proxies of the site, which suggest a dominance of the supramediterranean stage (Vidal-Matutano, 2016; Vidal-Matutano et al., 2018) or a turnover of the supramediterranean from SU Xb (Fagoaga et al., 2018) to a dominance of mesomediterranean in SU V (Fagoaga et al., 2019).

- The palaeoclimatic reconstruction draws a more or less stable context. The climate was cooler $\left(-0.87{ }^{\circ} \mathrm{C}\right.$ to $\left.-1.3^{\circ} \mathrm{C}\right)$ and more humid $(+305.31 \mathrm{~mm}$ to $+137.5 \mathrm{~mm})$ than the current climate in the area.

- Although our results are generally coincident with those inferred from mammals, the absolute values of the different bioclimatic parameters based on herpetofauna are higher than those based on small mammal assemblages.

- Whereas the studied bioclimatic parameters related with the temperature show a lower value for SU V than for SU Xb, the bioclimatic parameters related to rainfall (MAP, PDM, and PWM) are higher for the modern SU (SU V) than for the older SU Xb. Other proxies of the same site suggest the opposite situation (lower values for MAP, PDM, and PWM in SU V than those obtained in $\mathrm{Xb}$ ).

- Differences between the palaeoclimatic and palaeoecological reconstructions based on herpetofauna and small mammals may stem from the generally wide distribution range of the Iberian amphibians and reptiles in the Mediterranean bioregion and/or from some physiological particularities not detected in this study.

- Whether or not climate played a decisive role in the disappearance of Neanderthals remains uncertain. The extinction process of Neanderthals was complex and was probably the result of a synergy of multiple factors, rather than the product of a single cause. Moreover, the factors that provoked the disappearance of these humans could 
not have been the same in the different regions of their distribution area. In this sense, a multidisciplinary study is necessary to elucidate the causes that drove Neanderthals to their demise in the different regions of Iberia. In the case of El Salt, the climatic worsening scenario coincides with the progressive decrease in human activity, although this does not necessarily imply a causal connection.

\section{Declaration of Competing Interest}

The authors declare that they have no known competing financial interests or personal relationships that could have appeared to influence the work reported in this paper.

\section{Acknowledgements}

Research at El Salt is funded by the Spanish Government project HAR2015-68321-P (MINECO FEDER/UE), UV-INV_AE17-708551 (Universitat de València) and Conselleria d'Educació, Investigació, Cultura i Esport from the Valencian government. This investigation wasalso carried out thanks to the Prometeo Project of the Secretariat forHigher Education, Science, Technology and Innovation from Ecuadorand the University of La Laguna (Tenerife, Spain). The authors are grateful to Dr. Alfred Sanchis and Dra. Marta Calvo Revuelta who allowed us to consult the osteological material of the amphibian and reptile collections of the Gabinet de Fauna Quaternària in the Museu de Prehistòria de València and the Colección de Herpetología in the Museo Nacional de Ciencias Naturales (CSIC), respectively. Also, we would like to thank the El Salt excavation team for their help with the excavation, sieving and washing of sediment each year. We thank the editor and three anonymous reviewers for their comments, which greatly improved this manuscript. We are also grateful to Arturo Gamonal (Museo Paleontológico de Alpuente) and Jordi Guillem (Universitat de València) for his help with the English version.

\section{Appendix A. Supplementary data}

Supplementary data to this article can be found online at https://doi. org/10.1016/j.palaeo.2021.110372.

\section{References}

AHE, 2016. SIARE (Servidor de Informacion de Anfibios y Reptiles de España). Asociación Herpetológica Española. http://siare.herpetologica.es/bdh. Accessed January 2020.

Aiello, L.C., Wheeler, P., 2004. Neanderthal thermoregulation and the glacial climate. In: Van Andel, T.H., Davies, W. (Eds.), Neanderthals and Modern Humans in the European Landscape during the Last Glaciation. McDonald Institute Monographs, Cambridge, pp. 147-165.

Álvarez, Y., Mateo, J.A., Andreu, A.C., Díaz-Paniagua, C., Diez, A., Bautista, J.M., 2000. Mitochondrial DNA haplotyping of Testudo graeca on both continental sides of the Straits of Gibraltar. J. Hered. 91, 39-41. https://doi.org/10.1093/jhered/91.1.39. Andrews, P., 1990. Owls, caves and fossils. University of Chicago Press, London.

Andrews, P., 2006. Taphonomic effects of faunal impoverishment and faunal mixing. Palaeogeogr. Palaeoclimatol. Palaeoecol. 241, 572-589.

Antúnez, A., Real, R., Vargas, J.M., 1988. Análisis biogeográfico de los anfibios de la vertiente sur de la Cordillera Bética. Miscel-lània Zool. 12, 261-272.

Araújo, M.B., Pearson, R.G.M., 2005. Equilibrium of species' distributions with climate. Ecography 28, 693-695.

Auffenberg, W., 1967. The fossil snakes of Florida. Tulane Stud. Zool. 10, 131-216.

Bailon, S., 1991. Amphibiens et Reptiles Du Pliocene et de Du Quaternaire de France et D’Espagne: Mise En Place et Evolution Des Faunes (Ph. D. Thesis). Université Paris VII, France.

Bailon, S., 1999. No 1 Différenciation ostéologique des anoures (Amphibia, Anura) de France. In: Desse, J., Desse-Berset, N. (Eds.), Fiches d'óstéologie Animale Pour l'archéologie. Série C: Varia. Centre de Recherches Archéologiques - CNRS, Antibes, pp. 3-41.

Bailon, S., 2011. La taphonomie des amphibiens et des reptiles squamates: etat de la question. In: Laroulandie, V., Mallye, J.-B., Denys, C. (Eds.), Taphonomie des Petits Vertébrés: Référentiels et Transferts aux Fossils, British Archaeological Reports, International Series, 2269, pp. 33-41. Oxford.

Bailon, S., Blain, H.-A., 2007. Faunes de reptiles et changements climatiques en Europe occidentale autour de la limite Plio-Pléistocène. Quaternarie 18, 55-63.
Bailon, S., Rage, J.C., 1999. Amphibiens et reptiles du Quaternaire. Relations avec l’homme. Mém. Soc. géol. Fr. 160, 95-100.

Barahona, F., 1996. Osteología Craneal de Lacértidos de La Península Ibérica e Islas Canarias: Análisis Sistemático Filogenético (Ph. D. thesis). Universidad Autónoma de Madrid, Spain.

Barahona, F., Barbadillo, L.J., 1997. Identification of some Iberian lacertids using skull characters. Rev. Esp. Herp. 11, 47-62.

Barbadillo, L.J., 1989. Los reptilia (Sauria y Amphisbaenia) de los yacimientos PlioPleistocénicos de la Cuenca de Guadix-Baza. In: Alberti, M.T., Bonadonna, F.P. (Eds.), Geologia y Paleontologia de La Cuenca de Guadix-Baza, Trabajos Neogeno/ Quaternario. Museo Nacional de Ciéncias Naturales, Madrid, pp. 151-165.

Barbadillo, L.J., Garcia-Paris, M., Sanchiz, B., 1997. Orígenes y relaciones evolutivas de la herpetofauna ibérica. In: Pleguezuelos, J.M., Martínez-Rica, J.P. (Eds.), Distribución y biogeografía de los anfibios y reptiles de España. Monografías Revista Española de Herpetología, 3. Universidad de Granada, Granada, pp. 47-100.

Barroso Ruiz, C., Bailon, S., 2003. Los anfibios y los reptiles del Pleistoceno Superior de la Cueva del Boquete de Zafarraya (Málaga, España). In: Barroso Ruiz, C. (Ed.), El Pleistoceno Superior de la Cueva del Boquete de Zafarraya, Dirección General de Bienes Culturales. Servicio de Investigación y Difusión del Patrimonio Histórico, Consejería de Cultura, Junta de Andalucía, Sevilla, pp. 267-278.

Barroso Ruiz, C., Desclaux, E., Bailon, S., El Guennouni, K., Abbassi, M., 2003. La fauna de pequeños mamíferos de la Cueva del Boquete de Zafarraya. In: Barroso Ruiz, C. (Ed.), El Pleistoceno Superior de la Cueva del Boquete de Zafarraya, Dirección General de Bienes Culturales. Servicio de Investigación y Difusión del Patrimonio Histórico, Consejería de Cultura, Junta de Andalucía, Sevilla, pp. 223-250.

Beghin, P., Charbit, S., Kageyama, M., Combourieu-Nebout, N., Hatté, C., Dumas, C., Peterschmitt, J.Y., 2016. What drives LGM precipitation over the western Mediterranean? A study focused on the Iberian Peninsula and northern Morocco. Clim. Dyn. 46, 2611-2631. https://doi.org/10.1007/s00382-015-2720-0.

Birks, H.J.H., Heiri, O., Seppä, H., Bjune, A.E., 2010. Strengths and weakness of quantitative climate reconstructions based on late-quaternary biological proxies. Open Ecol. J. 3, 68-110. https://doi.org/10.2174/1874213001003020068.

Birks, H.H., Gelorini, V., Robinson, E., Zoek, W.Z., 2015. Impacts of palaeoclimate change $60000-8000$ years ago on humans and their environments in Europe: integrating palaeoenvironmental and archaeological data. Quat. Int. 378, 4-13. https://doi.org/10.1016/j.quaint.2014.02.022.

Bisbal-Chinesta, J.F., Blain, H.-A., 2018. Long-term changes in composition and distribution patterns in the Iberian herpetofaunal communities since the latest Pleistocene. Quat. Sci. Rev. 184, 143-166. https://doi.org/10.1016/j quascirev.2017.06.010.

Bisbal-Chinesta, J.F., Bañuls-Cardona, S., Fernández-García, M., Cáceres, I., Blain, H.A., Vergès, J.M., 2020a. Elucidating anuran accumulations: massive taphocenosis of tree frog Hyla from the Chalcolithic of El Mirador cave (Sierra de Atapuerca, Spain). J. Archaeol. Sci. Rep. 30, 102277. https://doi.org/10.1016/j.jasrep.2020.102277.

Bisbal-Chinesta, J.F., Tamar, K., Gálvez, Á., Albero, L., Vicent-Castelló, P., MartínBurgos, L., Alonso, M., Sánchez, R., Ortega, C., Gómez, A., Candel, D., Cervera, M., Carranza, S., Blain, H.-A., 2020b. Ancient trade and stowaways: molecular evidence for human-mediated translocation of eastern skinks into the western Mediterranean. Amphib-reptil 41, 49-62. https://doi.org/10.1163/15685381-20191249.

Blain, H.-A., 2009. Contribution de la paléoherpétofaune (Amphibia \& Squamata) à la connaissance de l'évolution du climat et du paysage du Pliocène supérieur au Pléistocène moyen d'Espagne. Treballs Mus. Geol. Barcelona 16, 39-170.

Blain, H.-A., Bailon, S., 2019. Extirpation of Ophisaurus (Anguimorpha, Anguidae) in Western Europe in the context of the disappearance of subtropical ecosystems at the Early Middle Pleistocene transition. Palaeogeogr. Palaeoclimatol. Palaeoecol. 520, 96-113. https://doi.org/10.1016/j.palaeo.2019.01.023.

Blain, H.-A., Bailon, S., Cuenca-Bescós, G., 2008. The Early-Middle Pleistocene palaeoenvironmental change based on the squamate reptile and amphibian proxy at the Gran Dolina site, Atapuerca, Spain. Palaeogeogr. Palaeoclimatol. Palaeoecol. 261, 177-192.

Blain, H.-A., Laplana, C., Sevilla, P., Arsuaga, J.L., Baquedano, E., Pérez-González, A., 2011a. MIS 5/4 transition in a mountain environment: herpetofaunal assemblages from Cueva del Camino, Central Spain. Boreas 43, 107-120. https://doi.org/ 10.1111/bor.12024.

Blain, H.-A., Bailon, S., Agustí, J., Martínez-Navarro, B., Toro, I., 2011b. Paleoenvironmental and paleoclimatic proxies to the Early Pleistocene hominids of Barranco León D and Fuente Nueva 3 (Granada, Spain) by means of their amphibian and reptile assemblages. Quat. Int. 243, 44-53. https://doi.org/10.1016/j. quaint.2010.12.031.

Blain, H.-A., Gleed-Owen, C.P., López-García, J.M., Carrión, J.S., Jennings, R., Finlayson, G., Finlayson, C., Giles-Pacheco, F., 2013. Climatic conditions for the last Neanderthals: Herpetofaunal record of Gorham's Cave, Gibraltar. J. Hum. Evol. 64, 289-299. https://doi.org/10.1016/j.jhevol.2012.11.003.

Blain, H.-A., Bailon, S., Agustí, J., 2016a. The geographical and chronological pattern of herpetofaunal Pleistocene extinctions on the Iberian Peninsula. C. R. Palevol. 15, 731-744. https://doi.org/10.1016/j.crpv.2015.05.008.

Blain, H.-A., Lozano-Fernández, I., Agustí, J., Bailon, S., Menéndez Granda, L., Espígares Ortiz, M.P., Ros Montoya, S., Jiménez Arenas, J.M., Toro-Moyano, I., MartínezNavarro, B., Sala, R., 2016b. Refining upon the climatic background of the Early Pleistocene hominid settlement in Western Europe: Barranco León and Fuente Nueva-3 (Guadix-Baza Basin, SE Spain). Quat. Sci. Rev. 144, 132-144. https://doi. org/10.1016/j.quascirev.2016.05.020.

Blain, H.A., Silva, J.A.C., Arenas, J.M.J., Margari, V., Roucoux, K., 2018. Towards a Middle Pleistocene terrestrial climate reconstruction based on herpetofaunal assemblages from the Iberian Peninsula: state of the art and perspectives. Quat. Sci. Rev. 191, 167-188. https://doi.org/10.1016/j.quascirev.2018.04.019. 
Blain, H.A., Bisbal-Chinesta, J.F., Martínez-Monzón, A., Panera, J., Rubio-Jara, S., Uribelarrea, D., Sáinz de los Terreros, J.Y., Pérez-González, A., 2019. The middle to Late Pleistocene herpetofaunal assemblages from the Jarama and Manzanares valleys (Madrid, central Spain): an ecological synthesis. Quat. Int. 520, 49-63. https://doi.org/10.1016/j.quaint.2018.03.004.

Boone, M.D., Corn, P.S., Donnelly, M.A., Little, E.E., Niewaiarowski, P.H., 2003. Physical stressors. In: Linder, G., Krest, S.K., Sparling, D.W. (Eds.), Global Decline of Amphibians Populations: An Integrated Analysis of Multiple Stressor Effects. Society of Environmental Toxicology and Chemistry, Pensacola, Florida, pp. 129-151.

Bradley, R.S., 1999. Paleolimatology. Reconstructing Climates of the Quaternary. International Geophysics Series, 64. Academic Press, Burlington.

Bradtmöller, M., Pastoors, A., Weniger, B., Weniger, G.C., 2012. The repeated replacement model-Rapid climate change and population dynamics in late Pleistocene Europe. Quat. Int. 247, 38-49. https://doi.org/10.1016/j. quaint.2010.10.015.

Burjachs, F., Giralt, S., Riera Mora, S., Roca, J.R., Julià, R., 1996. Evolución paleoclimática durante el último ciclo glaciar en la vertiente mediterránea de la Península Ibérica. Notes Geogr. Fís. 25, 21-39.

Burjachs, F., López-García, J.M., Allué, E., Blain, H.-A., Rivals, F., Bennàsar, M., Expósito, I., 2012. Palaeoecology of Neanderthals during Dansgaard-Oeschger cycles in northeastern Iberia (Abric Romaní): from regional to global scale. Quat. Int. 247, 26-37. https://doi.org/10.1016/j.quaint.2011.01.035.

Castillo, C., Martín-González, E., Coello, J.J., 2001. Small vertebrate taphonomy of La Cueva del Llano, a volcanic cave on Fuerteventura (Canary Islands, Spain). Palaeoecological implications. Palaeogeogr. Palaeoclimatol. Palaeoecol. 166, 277-291. https://doi.org/10.1016/S0031-0182(00)00213-3.

Cochard, D., 2004. Mise en évidence d'une accumulation de batraciens par mortalité catastrophique en masse. In: Brugal, J.P., Desse, J. (Eds.), Petits Animaux et Société Humaines. Du complément alimentaire aux ressources utilitaires. Éditions APDCA, Antibes, pp. 471-474.

Cohen, A., Arrowsmith, R., Behrensmeyer, A.K., Campisano, C., Feibel, C., Fisseha, S., Johnson, R., Kubsa Bedaso, Z., Lockwood, C., Mbua, E., Olago, D., Potts, R., Reed, K. Renaut, R., Tiercelin, J.-J., Umer, M., 2009. Understanding paleoclimate and human evolution through the Hominin Sites and Paleolakes Drilling Project. Sci. Drill. 8, 60-65.

Cruz, J.A., Arroyo-Cabrales, J., Reynoso, V.H., 2016. Reconstructing the paleoenvironment of Loltún Cave, Yucatán, Mexico, with Pleistocene amphibians and reptiles and their paleobiogeographic implications. Rev. Mex. Cienc. Geol. 33, 342-354.

Cuenca-Bescós, G., Rofes, J., García-Pimienta, J.C., 2005. Early Europeans and environmental change across the Early-Middle Pleistocene transition: Small mammalianevidence from Trinchera Dolina cave, Atapuerca, Spain. In: Head, M.J. Gibbard, P.L. (Eds.), Early-Middle Pleistocene Transitions: The Land Ocean Evidence. Geological Society of London, London, pp. 277-286. Special Publications, 27.

Daura, J., Sanz, M., García, N., Allué, E., Vaquero, M., Fierro, E., Carrión, J.S., LópezGarcía, J.M., Blain, H.-A., Sánchez-Marco, A., Valls, C., Albert, R.M., Fornós, J.J., Julià, R., Fullola, J.M., Zilhão, J., 2013. Terrasses de la Riera dels Canyars (Gavà, Barcelona): the landscape of Heinrich Stadial 4 north of the "Ebro frontier" and implications for modern human dispersal into Iberia. Quat. Sci. Rev. 60, 26-48.

deMenocal, P.B., 2011. Climate and human evolution. Science 331, 540-542. https:// doi.org/10.1126/science.1190683.

d'Errico, F., Sánchez Goñi, M.F., 2003. Neanderthal extinction and the millennial scale climatic variability of OIS 3. Quat. Sci. Rev. 22, 769-788. https://doi.org/10.1016/ S0277-3791(03)00009-X.

Evans, E.M.N., Van Couvering, J.A.H., Andrews, P., 1981. Palaeoecology of Miocene sites in western Kenya. J. Hum. Evol. 10, 99-116.

Evershed, R.P., Bull, I.D., Corr, L.T., Crossman, Z.M., Van Dongen, B.E., Evans, C.J., Jim, S., Mottram, H.R., Mukherjee, A.J., Pancost, R.D., 2007. Compound-specific stable isotope analysis in ecology and paleoecology. In: Michener, R., Lajtha, K. (Eds.), Stable Isotopes in Ecology and Environmental Science. Blackwell Publishing, Singapore, pp. 480-540.

Fagoaga, A., 2019. Estudio paleoambiental de la región central del Mediterráneo ibérico durante el Pleistoceno a partir de las faunas de microvertebrados de los yacimiento de El Salt y Abric del Pastor (Alcoi, Alicante) (Ph. D. Thesis). Universitat de València, Spain.

Fagoaga, A., Ruiz-Sánchez, F.J., Laplana, C., Blain, H.-A., Marquina, R., MarinMonfort, M.D., Galván, B., 2018. Palaeoecological implications of Neanderthal occupation at Unit $\mathrm{Xb}$ of El Salt (Alcoi, eastern Spain) during MIS 3 using small mammals proxy. Quat. Int. 481, 101-112. https://doi.org/10.1016/j. quaint.2017.10.024

Fagoaga, A., Laplana, C., Marquina-Blasco, R., Machado, J., Marin-Monfort, M.D. Crespo, V.D., Hernández, C.M., Mallol, C., Galván, B., Ruiz-Sánchez, F.J., 2019. Palaeoecological context for the extinction of the Neanderthals: a small mammal study of stratigraphic Unit V of the El Salt site, Alcoi, eastern Spain. Palaeogeogr. Palaeoclimatol. Palaeoecol. 530, 163-175. https://doi.org/10.1016/j. palaeo.2019.05.007.

Fernández-García, M., López-García, J.M., Bennàsar, M., Gabucio, M.J., Bargalló, A., Chacón, M.G., Saladié, P., Vallverdú, J., Vaquero, M., Carbonell, E., 2018. Paleoenvironmental context of Neanderthal occupations in northeastern Iberia: the small-mammal assemblage from Abric Romaní (Capellades, Barcelona, Spain). Palaeogeogr. Palaeoclimatol. Palaeoecol. 506, 154-167. https://doi.org/10.1016/j. palaeo.2018.06.031.

Fernández-García, M., López-García, J.M., Royer, A., Lécuyer, C., Allué, E., Burjachs, F., Chacon, M.G., Saladié, P., Vallverdú, J., Carbonell, E., 2020. Combined palaeoecological methods using small-mammal assemblages to decipher environmental context of a long-term Neanderthal settlement in northeastern Iberia. Quat. Sci. Rev. 228, 106072. https://doi.org/10.1016/j.quascirev.2019.106072.

Finlayson, C., 2004. Neanderthals and Modern Humans: An Ecological and Evolutionary Perspective. Cambridge University Press, Cambridge.

Finlayson, C., 2005. Biogeography and evolution of the genus Homo. Trends Ecol. Evol. 20, 457-463. https://doi.org/10.1016/j.tree.2005.05.019.

Finlayson, J.C., Carrión, J.S., 2007. Rapid ecological turnover and its impact on Neanderthal and other human populations. Trends Ecol. Evol. 22, 213-222. https:// doi.org/10.1016/j.tree.2007.02.001.

Finlayson, C., Giles-Pacheco, F., 2000. The Southern Iberian Peninsula in the Late Pleistocene: geography, ecology and human occupation. In: Stringer, C.B., Barton, R. N.E., Finlayson, J.C. (Eds.), Neanderthals on the Edge: Papers from a Conference Marking the 150th Anniversary of the Forbes' Quarry Discovery, Gibraltar. Oxbow Books, Oxford, pp. 140-153.

Finlayson, J.C., Barton, R.N.E., Stringer, C.B., 2001. The Gibraltar Neanderthals and their extinction. In: Zilhão, J., Aubry, T., Faustino Carvalho, A. (Eds.), Les premiers hommes modernes de la Péninsule Ibérique. Trabalhos de Arqueologia, Lisboa, pp. 117-122.

Fletcher, W., Sánchez-Goñi, M.A., 2008. Orbital and sub-orbital scale climate impacts on vegetation of the Western Mediterranean basin over the last 48000 years. Quat. Res. 70, 451-464. https://doi.org/10.1016/j.yqres.2008.07.002.

Fumanal García, M.P., 1994. El yacimiento musteriense de el Salt (Alcoi, País Valenciano). Rasgos geomorfológicos y climatoestratigrafía de sus registros. Saguntum 27, 39-55.

Galván, B., Hernandez, C.M., Mallol, C., Mercier, N., Sistiaga, A., Soler, V., 2014a. New evidence of early Neanderthal disappearance in the Iberian Peninsula. J. Hum. Evol. 75, 16-27. https://doi.org/10.1016/j.jhevol.2014.06.002.

Galván, B., Hernández, C.M., Mallol, C., Machado, J., Sistiaga, A., Molina, F.J., Pérez, L., Afonso, R., Garralda, M.D., Mercier, N., Morales, J.V., Sanchís, A., Tarriño, A., Gómez, J.A., Abreu, I., Vidal, P., 2014b. El Salt. Últimos neandertales de la montaña alicantina (Alcoy, España). In: Sala, R., Carbonell, E., Bermúdez de Castro, J.M., Arsuaga, J.L. (Eds.), Los cazadores recolectores del Pleistoceno y del Holoceno en Iberia y el estrecho de Gibraltar: estado actual del conocimiento del registro arqueológico. Universidad de Burgos, Burgos, pp. 380-388.

Garcia-Ibaibarriaga, N., Suárez-Bilbao, A., Bailon, S., Arrizabalaga, A., IriarteChiapusso, M.-J., Arnold, L., Demuro, M., Murelaga, X., 2018. Paleoenvironmental and paleoclimatic interpretation of the stratigraphic sequence of Lezetxiki II Cave (Basque Country, Iberian Peninsula) inferred from small vertebrate assemblages. Quat. Res. 90, 164-179. https://doi.org/10.1017/qua.2018.17.

Garralda, M.D., Galván, B., Hernández, C.M., Mallol, C., Gómez, J.A., Maureille, B., 2014. Neanderthals from El Salt (Alcoy, Spain) in the context of the latest Middle Palaeolithic populations from the southeast of the Iberian Peninsula. J. Hum. Evol. 75, 1-15. https://doi.org/10.1016/j.jhevol.2014.02.019.

Gómez de la Rúa, D., Mallol Duque, C., Galván Santos, B., Hernández Gómez, C.M., 2010. Una visión geoarqueológica general del yacimiento musteriense de El Salt (Alcoy, Alicante) a partir de la micromorfología. Recerques del Mus. d'Alcoi 19, 19-32.

Hijmans, R.J., Cameron, S.E., Parra, J.L., Jones, P.G., Jarvis, A., 2005. Very high resolution interpolated climatesurfaces for global land areas. Int. J. Climatol. 25, 1965-1978. https://doi.org/10.1002/joc.1276.

Holmes, J.A., Atkinson, T., Darbyshire, D.F., Horne, D.J., Joordens, J., Roberts, M.B., Sinka, K.J., Whittaker, J.E., 2010. Middle Pleistocene climate and hydrological environment at the Boxgrove hominin site (West Sussex,UK) from ostracod records. Quat. Sci. Rev. 29, 1515-1527. https://doi.org/10.1016/j.quascirev.2009.02.024.

Jasić, F.M., Marti, C.D., 1984. Comparative food habits of Bubo owls in mediterraneantype ecosystems. Condor 86, 288-296.

Jennerjahn, T.C., Ittekkot, V., Arz, H.W., Behling, H., Pätzold, J., Wefer, G., 2004. Asynchronous terrestrial and marine signals of climate change during Heinrich events. Science 306, 2236-2239. https://doi.org/10.1126/science.1102490.

Lambeck, K., Bard, E., 2000. Sea-level change along the French Mediterranean coast for the past 30000 years. Earth Planet. Sci. Lett. 175, 203-222.

Lebreton, L., Bailon, S., Guillaud, E., Testu, A., Perrenoud, C., 2020. Multi-taxa referential of a modern Eurasian Eagle-Owl (Bubo bubo) aerie. J. Archaeol. Sci. Rep. $32,102417$.

Lizana, M., 2002. Bufo bufo (Linnaeus, 1758). Sapo común, Escuerzo. In: Pleguezuelos, J. M., Márquez, R., Lizana, M. (Eds.), Atlas y Libro Rojo de los Anfibios y Reptiles de España. Dirección General de Conservación de la Naturaleza and Asociación Herpetológica Española, Madrid, pp. 103-106.

López-García, J.M., Cuenca-Bescós, G., Blain, H.-A., Álvarez-Lao, D., Uzquiano, P., Adán, G., Arbizu, M., Arsuaga, J.L., 2011a. Palaeoenvironment and palaeoclimate of the Mousterian-Aurignacian transition in northern Iberia: the small-vertebrate assemblage from Cueva del Conde (Santo Adriano, Asturias). J. Hum. Evol. 61, 108-116. https://doi.org/10.1016/j.jhevol.2011.01.010.

López-García, J.M., Cuenca-Bescós, G., Finlayson, C., Brown, K., Pacheco, F.G., 2011b. Palaeoenvironmental and palaeoclimatic proxies of the Gorham's cave small mammal sequence, Gibraltar, southern Iberia. Quat. Int. 243, 137-142.

López-García, J.M., Blain, H.-A., Burjachs, F., Ballesteros, A., Allué, E., Cuevas-Ruiz, G.E., Rivals, F., Blasco, R., Morales, J.I., Rodríguez Hidalgo, A., Carbonell, E., Serrat, D., Rosell, J., 2012a. A multidisciplinary approach to reconstructionf the chronology and environment of southwestern European Neanderthals: the contribution of Teixoneres cave (Moià, Barcelona, Spain). Quat. Sci. Rev. 43, 33-44. https://doi. org/10.1016/j.quascirev.2012.04.008.

López-García, J.M., Blain, H., Bennàsar, M., Euba, I., Bañuls, S., Bischoff, J., LópezOrtega, E., Saladié, P., Uzquiano, P., Vallverdú, J., 2012b. A multiproxy reconstruction of the palaeoenvironment and palaeoclimate of the late pleistocene in northeastern Iberia: Cova dels Xaragalls, Vimbodí-Poblet, Paratge Natural de Poblet, Catalonia. Boreas 41, 235-249. 
López-García, J.M., Blain, H.-A., Sanz, M., Daura, J., 2012c. A coastal reservoir of terrestrial resources for Neanderthal populations in North-Eastern Iberia: palaeoenvironmental data inferred from the small-vertebrate assemblage of Cova del Gegant, Sitges, Barcelona. J. Quat. Sci. 27, 105-113. https://doi.org/10.1002/ jqs.1515.

López-García, J.M., Blain, H.-A., Bennàsar, M., Sanz, M., Daura, J., 2013. Heinrich event 4 characterized by terrestrial proxies in southwestern Europe. Clim. Past 9, 1053-1064. https://doi.org/10.5194/cp-9-1053-2013.

López-García, J.M., Blain, H., Bennàsar, M., Fernández-García, M., 2014. Environmental and climatic context of Neanderthal occupation in southwestern Europe during MIS3 inferred from the small-vertebrate assemblages. Quat. Int. 326, 319-328. https:// doi.org/10.1016/j.quaint.2013.09.010.

López-García, J.M., Soler, N., Maroto, J., Soler, J., Alcalde, G., Galobart, À. Bennàsar, M., Burjachs, F., 2015. Palaeoenvironmental and palaeoclimatic reconstruction of the latest Pleistocene of L'Arbreda Cave (Serinyà, Girona, northeastern Iberia) inferred from the small-mammal (insectivore and rodent) assemblages. Palaeogeogr. Palaeoclimatol. Palaeoecol. 435, 244-253. https://doi. org/10.1016/J.PALAEO.2015.06.022.

Loureiro, A., de Almeida, N.F., Carretero, M.A., Paulo, O.S., 2008. Atlas Dos Anfíbios e Répteis de Portugal, 1st Editio. Instituto da Conservação da Natureza e da Biodiversidade, Lisboa.

Lyman, R.L., 1994. Vertebrate Taphonomy. Cambridge University Press, Cambridge.

Mallol, C., Hernández, C.M., Machado, J., 2012. The significance of stratigraphic discontinuities in Iberian Middle-to-Upper Palaeolithic transitional sites. Quat. Int. 275, 4-13. https://doi.org/10.1016/j.quaint.2011.07.026.

Marquina, R., Fagoaga, A., Crespo, V.D., Ruiz-Sánchez, F.J., Bailon, S., Hernández, C.M., Galván, B., 2017. Amphibians and squamate reptiles from the stratigraphic unit Xb of El Salt (Middle Palaeolithic; Alcoy, Spain): palaeoenvironmental and palaeoclimatic implications. Spanish J. Palaeontol. 32, 219-312. https://doi.org/ 10.7203/sjp.32.2.17045.

Melchionna, M., Di Febbraro, M., Carotenuto, F., Rook, L., Mondanaro, A. Castiglione, S., Serio, C., Vero, V.A., Tesone, G., Piccolo, M., Diniz-Filho, J.A.F., Raia, P., 2018. Fragmentation of Neanderthals' pre-extinction distribution by climate change. Palaeogeogr. Palaeoclimatol. Palaeoecol. 496, 146-154.

Mellars, P., 2004. Neanderthals and the modern human colonization of Europe. Nature 432, 461-465. https://doi.org/10.1038/nature03103.

Morales Pérez, J.V., Sanchis Serra, A., 2009. The Quaternary fossil record of the genus Testudo in the Iberian Peninsula. Archaeological implications and diachronic distribution in the western Mediterranean. J. Archaeol. Sci. 36, 1152-1162. https:// doi.org/10.1016/j.jas.2008.12.019.

Moreno, A., Cacho, I., Canals, M., Prins, M.A., Sánchez-Goñi, M.F., Grimalt, J.O. Weltje, G.J., 2002. Saharan dust transport and high-latitude glacial climatic variability: the Alboran Sea record. Quat. Res. 58, 318-328. https://doi.org/ 10.1006/qres.2002.2383.

Nabais, M., Zilhão, J., 2019. The consumption of tortoise among last interglacial Iberian Neanderthals. Quat. Sci. Rev. 217, 225-246.

Ninyerola, M., Pons, X., Roure, J.M., 2005. Atlas Climático Digital de la Península Ibérica. Metodología y Aplicaciones en Bioclimatología y Geobotánica. Universitat Autònoma de Barcelona, Barcelona.

Paulo, O.S., Pinto, I., Bruford, M.W., Jordan, W.C., Nichols, R.A., 2002. The double origin of Iberian peninsular chameleons. Biol. J. Linn. Soc. 75, 1-7.

Pearson, O.M., 2000. Activity, climate, and postcranial robusticity. Curr. Anthropol. 41, 569-607. https://doi.org/10.1086/317382.

Pérez-Santigosa, N., Díaz-Paniagua, C., Hidalgo-Vila, J., 2008. The reproductive ecology of exotic Trachemys scripta elegans in an invaded area of southern Spain. Aquat. Conserv. Mar. Freshwat. Ecosyst. 18, 1302-1310.

Pinto Llona, A.C., Andrews, P.J., 1999. Amphibian taphonomy and its application to the fossil record of Dolina (middle Pleistocene, Atapuerca, Spain). Palaeogeogr. Palaeoclimatol. Palaeoecol. 149, 411-429.

Pleguezuelos, J.M., Márquez, R., Lizana, M., 2002. Atlas y Libro Rojo de Los Anfibios y Reptiles de España, 2a impresión. Dirección General de Conservación de la Naturaleza-Asociación Herpetologica Española, Madrid.

Rae, T.C., Koppe, T., Stringer, C.B., 2011. The Neanderthal face is not cold adapted. J. Hum. Evol. 60, 234-239.

Railsback, L.B., Gibbard, P.L., Head, M.J., Voarintsoa, N.R.G., Toucanne, S., 2015. An optimized scheme of lettered marine isotope substages for the last 1.0 million years, and the climatostratigraphic nature of isotope stages and substages. Quat. Sci. Rev. 111, 94-106. https://doi.org/10.1016/j.quascirev.2015.01.012.

Rey-Rodríguez, I., López-García, J.-M., Bennàsar, M., Bañuls-Cardona, S., Blain, H.-A., Blanco-Lapaz, D., Rodríguez-Álvarez, X.P., de Lombera-Hermida, A., DíazRodríguez, M., Ameijenda-Iglesias, A., Agustí, J., Fábregas-Valcarce, R., 2016. Last Neanderthals and first Anatomically Modern Humans in the NW Iberian Peninsula: climatic and environmental conditions inferred from the Cova Eirós small-vertebrate assemblage during MIS 3. Quat. Sci. Rev. 151, 185-197.

Rivas-Martínez, S., 1987. Memoria Del Mapa de Series de Vegetación de España [Escala] 1: 400.000. Instituto Nacional para la Conservación de la Naturaleza, Madrid.

Roček, Z., 1984. Lizards (Reptilia, Sauria) from the lower Miocene locality Dolnice (Bohemia, Czechoslovakia). Rozpravy Ceskoslovenské Akademie Ved, Rada Matematickych a prírodních Ved 94, 3-69.

Rodríguez, M.A., Belmontes, J.A., Hawkins, B.A., 2005. Energy, water and large-scale patternsof reptile and amphibian species richness in Europe. Acta Oecol. 28, 65-70. https://doi.org/10.1016/j.actao.2005.02.006.

Rose, J., Meng, X., Watson, C., 1999. Palaeoclimate and palaeoenvironmental responses in the western Mediterranean over the last 140 ka: evidence from Mallorca, Spain. J. Geol. Soc. 156, 435-448.
Saint Girons, H., 1980. Biogéographie et évolution des vipères européennes. C. r. séanches Soc. Biogêogr. 496, 146-172.

Sánchez Goñi, M.F., Landais, A., Cacho, I., Duprat, J., Rossignol, L., 2009. Contrasting intrainterstadial climatic evolution between high and middle North Atlantic latitudes: a close-up of Greenland Interstadials 8 and 12. Geochem. Geophys. Geosyst. 10 https://doi.org/10.1029/2008GC002369. Q04U04.

Sanchiz, B., 1998. Encyclopedia of Paleoherpetology. Part 4. Salientia. Verlag Dr. Friedrich Pfeil, München.

Santos, X., 2008. Natrix maura (Linnaeus, 1758). In: Loureiro, A., Ferrand de Almeida, N., Carretero, M.A., Paulo, O.S. (Eds.), Atlas dos Anfíbios e Répteis de Portugal. Instituto da Conservação da Natureza e da Biodiversidade, Lisboa, pp. 176-177.

Santos, X., Llorente, G.A., Montori, A., Carretero, M.A., 2002. Natrix maura (Linnaeus, 1758). Culebra viperina. In: Pleguezuelos, J.M., Márquez, R., Lizana, M. (Eds.), Atlas y Libro Rojo de los Anfibios y Reptiles de España. Dirección General de Conservación de la Naturaleza-Asociación Herpetológica Española, Madrid, pp. 290-292.

Santos, X., Roca, J., Pleguezuelos, J.M., Donaire, D., Carranza, S., 2008. Biogeography and evolution of the Smooth snake Coronella austriaca (Serpentes: Colubridae) in the Iberian Peninsula: evidence for Messinian refuges and Pleistocene range expansions. Amphib-reptil 29, 35-47.

Schmitt, D., Churchill, S.F., Hylander, W.L., 2003. Experimental evidence concerning spear use in Neanderthals and early modern humans. J. Archaeol. Sci. 30, 103-114.

Sepulchre, P., Ramstein, G., Kageyama, M., Vanhaeren, M., Krinner, G., SánchezGoñi, M.-F., d'Errico, F., 2007. H4 abrupt event and late Neanderthal presence in Iberia. Earth Planet. Sci. Lett. 258, 283-292. https://doi.org/10.1016/j epsl.2007.03.041.

Sillero, N., Brito, J.C., Skidmore, A.K., Toxopeus, A.G., 2009. Biogeographical patterns derived from remote sensing variables: the amphibians and reptiles of the Iberian Peninsula. Amphib-reptil 30, 185-206.

Speybroeck, J., Beukema, W., Dufresnes, C., Fritz, U., Jablonski, D., Lymberakis, P., Martínez-Solano, I., Razzetti, E., Vamberger, M., Vences, M., Vörös, J., Crochet, P.A., 2020. Species list of the European herpetofauna - 2020 update by the Taxonomic Committee of the Societas Europaea Herpetologica. Amphib-reptil 41, 139-189. https://doi.org/10.1163/15685381-bja10010.

Stewart, J.R., 2004. Neanderthal-Modern Human Competition? A comparison between the mammals associated with Middle and Upper Palaeolithic industries in Europe during OIS 3. Int. J. Osteoarchaeol. 14, 178-189.

Stewart, J.R., 2005. The ecology and adaptation of Neanderthals during the nonanalogue environment of Oxygen Isotope Stage 3. Quat.Int. 137, 35-46.

Stewart, J.R., 2009. The evolutionary consequence of the individualistic response to climate change. J. Evol. Biol. 22, 2362-2375.

Stewart, J.R., García-Rodríguez, O., Knul, M.V., Sewell, L., Montgomery, H., Thomas, M. G., Diekmann, Y., 2019. Palaeoecological and genetic evidence for Neanderthal power locomotion as an adaptation to a woodland environment. Quat. Sci. Rev. 217, 310-315.

Stoetzel, E., Denys, C., Bailon, S., El Hajraoui, M.A., Nespoulet, R., 2011. 1 Taphonomic Analysis of Amphibian and Squamate remains from El Harhoura 2 (Rabat Témara, Morocco): contributions to Palaeoecologicaland Archaeological Interpretations. Int. J. Osteoarchaeol. 22, 616-635. https://doi.org/10.1002/oa.1275.

Strauss, L.G., 2018. The upper paleolithic of Iberia. Trab. Prehist. 75, 9-51.

Szyndlar, Z., 1984. Fossil snakes from Poland. Acta Zool. Cracov. 28, 1-156.

Szyndlar, Z., Rage, J.C., 1999. Oldest fossil vipers (Serpentes: Viperidae) from the old world. Kaupia 8, 9-20.

Thomas, H., Triolet, L., 1994. Observations sur le développement et les moeurs troglophiles de Pelodytes punctatus (Amphibien anoure, Pelobatide). Bull. Soc. linn. Bordx. 22, 199-205.

Trinkaus, E., 1995. Neanderthal mortality patterns. J. Archaeol. Sci. 22, 121-142.

Turner, C., Hannon, G.E., 1988. Vegetational evidence for late Quaternary climatic changes in Southwest Europe in relation to the influence of the North Atlantic Ocean, Philos. Trans. R. Soc. Lond. Ser. B Biol. Sci. 318, 451-485.

Van Andel, T.H., 2003. Humans in an ice age-The stage 3 project: Overture or finale? Epilogue. In: Van Andel, T.H., Davies, W. (Eds.), Neanderthals and Modern Humans in the European Landscape during the Last Glaciation, 60,000 to 20,000 Years Ago: Archaeological Results of the Stage Three Project, pp. 257-265. McDonald Institute Monograph Series, Cambridge.

Vaquero, M., Maroto, J., Arrizabalaga, A., Baena, J., Baquedano, E., Carrión, E., Jordá, J. J., Martinón, M., Menéndez, M., Montes, R., Rosell, J., 2006. The Neandertal-Modern Human meeting in Iberia: A critical view of the cultural, geographical and chronological data. In: Conard, N.J. (Ed.), When Neanderthals and Moderns Met. Kerns Verlag, Tübingen, pp. 419-439.

Vargas, J.M., Real, R., 1997. Biogeografía de los anfibios y reptiles de la península ibérica. In: Pleguezuelos, J.M. (Ed.), Distribución y Biogeografía de Los Anfibios y Reptiles En España y Portugal. Asociación Herpetológica Española and Universidad de Granada, Granada, pp. 310-320.

Vidal-Matutano, P., 2016. Alrededor del fuego: paisaje, clima y gestión de los recurso leñosos en grupos cazadores-recolectores durante el Paleolítico medio (Alicante, España). Universitat de València, Spain.

Vidal-Matutano, P., 2018. Anthracological data from Middle Palaeolithic contexts in Iberia: what do we know? Munibe Antropol.-Arkeologia 69, 5-20.

Vidal-Matutano, P., Pérez-Jordà, G., Hernández, C.M., Galván, B., 2018. Macrobotanical evidence (wood charcoal and seeds) from the Middle Palaeolithic site of El Salt, Eastern Iberia: palaeoenvironmental data and plant resources catchment areas. J. Archaeol. Sci. Rep. 19, 454-464. https://doi.org/10.1016/j.jasrep.2018.03.032.

Villa, A., Blain, H.-A., Delfino, M., 2018a. The Early Pleistocene herpetofauna of Rivoli Veronese (Northern Italy) as evidence for humid and forested glacial phases in the Gelasian of Southern Alps. Palaeogeogr. Palaeoclimatol. Palaeoecol. 490, 393-403. 
Villa, A., Blain, H.-A., van den Hoek Ostende, L.W., Delfino, M., 2018b. Fossil amphibians and reptiles from Tegelen (Province of Limburg) and the early Pleistocene palaeoclimate of the Netherlands. Quat. Sci. Rev. 187, 203-2019. https://doi.org/10.1016/j.quascirev.2018.03.020.

Vitt, L.J., Caldwell, J.P., 2013. Herpetology: An Introductory Biology of Amphibians and Reptiles, 4th ed. Academic Press, Waltham. 776 p.

Wolf, D., Kolb, T., Alcaraz-Castaño, M., Heinrich, S., Baumgart, P., Calvo, R., Sánchez, J., Ryborz, K., Schäfer, I., Bliedtner, M., Zech, R., Zöller, L., Faust, D., 2018. Climate deteriorations and Neanderthal demise in interior Iberia. Sci. Rep. 8, 7048. https:// doi.org/10.1038/s41598-018-25343-6.

Wood, R.E., Barroso, C., Caparrós, M., Jordá, J.F., Galván, B., Davidson, I., Higham, T.F. G., 2013. Radiocarbon datingcasts doubt on the late chronology of the Middle to Upper Palaeolithic transition in southern Iberia. Proc. Natl. Acad. Sci. U. S. A. 110, 2781-2786. https://doi.org/10.1073/pnas.1207656110. 